رواية أحمدُ عن الثافعي"

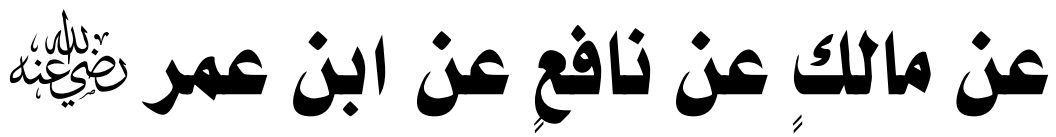
وقيتها الرفيعة عند المحدثين

بقلم

أسامة السيد محمود محمد

مدرس الحديث الشريف وعلومه بكلية أصول الدين بالزقازيق 


$$
\text { بسم الله الرحمن الرحيم }
$$

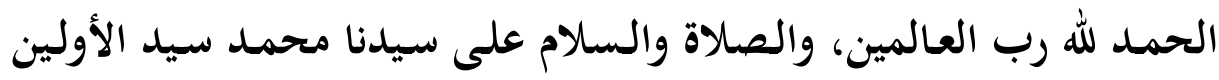
والآخرين، وخاتم النبيين والمرسلين، ورحمة الله للعالمين، وعلى آله وصحبه ومن ولهن تبعهم بإحسان إلى يوم الدين. أما بعد.......

فهذا بحث حديثيُّ، في سندِ شريفٍ، تسلسل برواية الأئمة الأكابر : أبي عبد

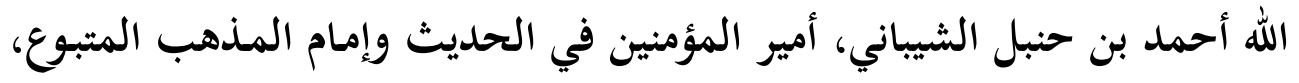

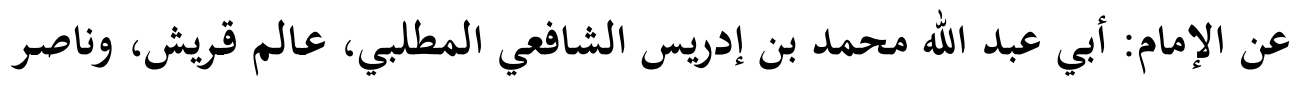

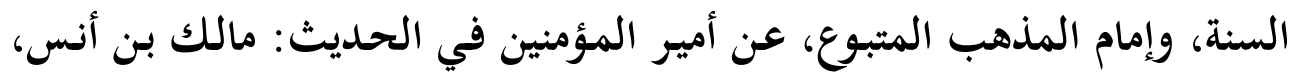

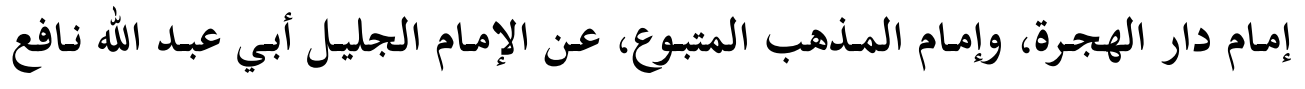
مولى ابن عمر، عن سيدنا عبد الله بن عمر رضي الله تعالى عنهم أجمعين.

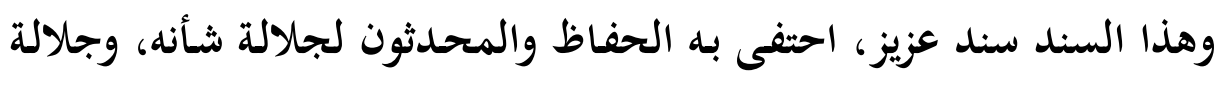

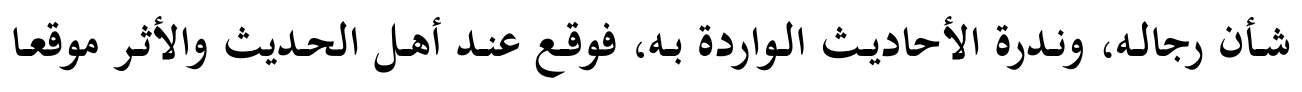

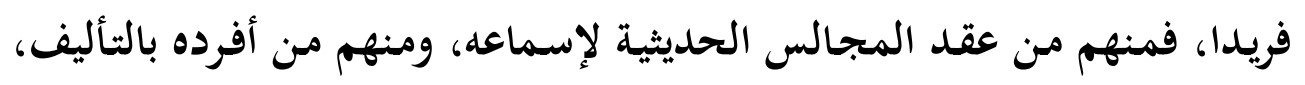
مع توارد عدد من الحفاظ على التنبيه على جلال موقعه، حتى سماه الإمام التاج السبكي ب(عقد الجوهر) كما سيأتي.

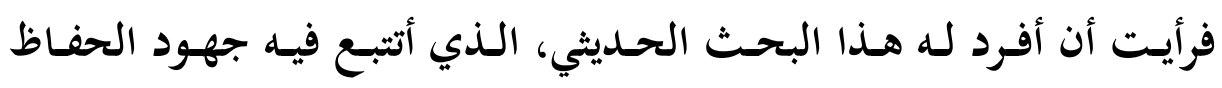
والمحدثين حول هذا السند الجليل، وقد أدرت هذا البحث على ستة مباحث:

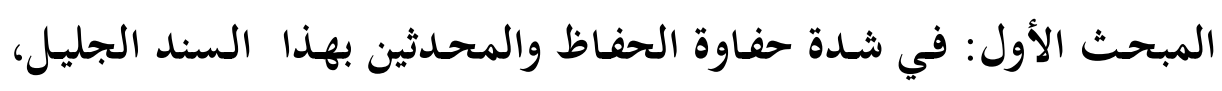
حتى أفردوا المجالس لإسماعل، وكان أحد الأئمة يحدث به به مرة في السنة 


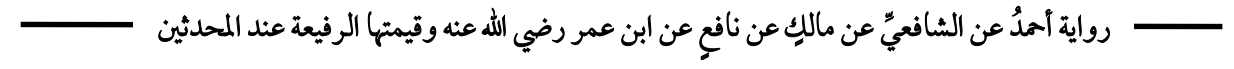

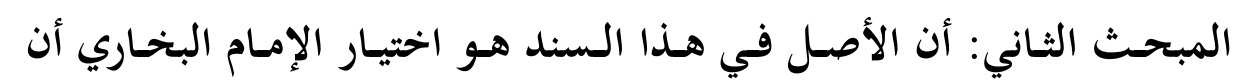
ترجمة مالك عن نافع عن ابن عمر هي أصح الأسانيد.

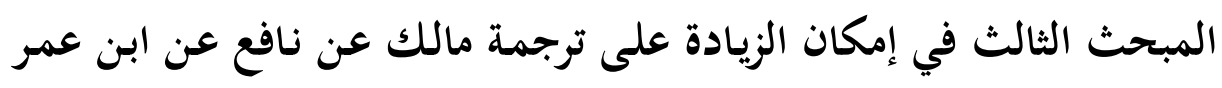
من جنسها، وتحول سلسلة الذهب إلى عقد الجوهر.

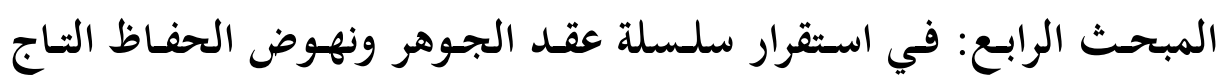
السبكي والسخاوي والسيوطي إلى الحفاوة بها سوق أسانيدهم إليها.

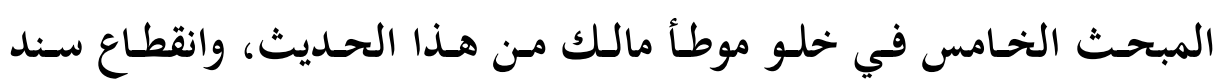
الموطأ برواية الشافعي رغم أنه أقرأه للإمام أحمد.

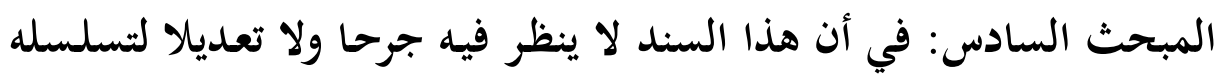
بالأئمة الحفاظ واستفاضة إمامة رجاله.

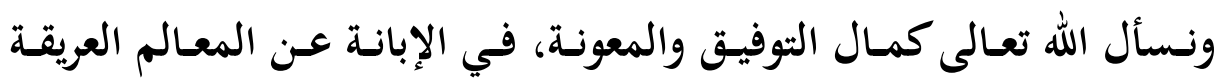

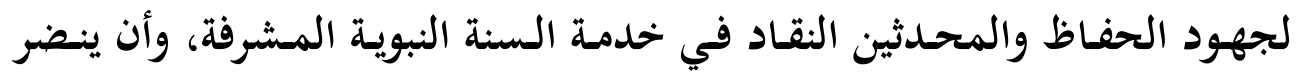
وجوهنا بنضرة أهل الحديث، وعليه سبحانه التكلان. 


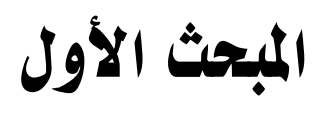

في شدة حفاوة الحفاظ والمحدثين بهذا السند الجليل، حتى

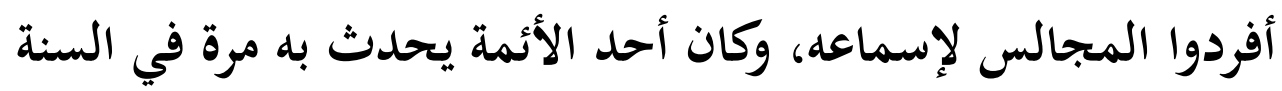

احتفى الأئمةُ وأهلُ الحديث بهذا السند -بل وبرواية أحمد عن الشافعي عن

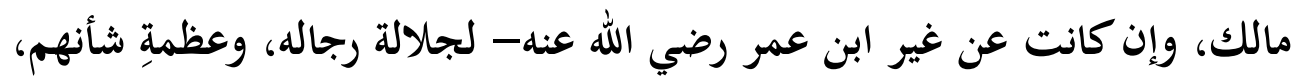

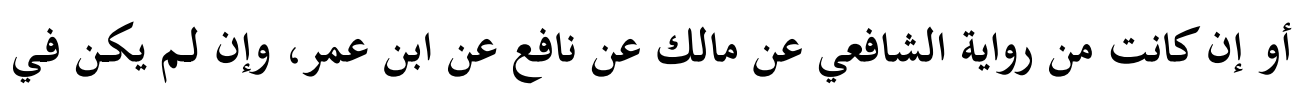

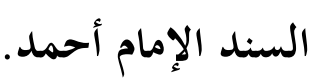

حتى إنَّ أحدَ الأئمةِ، وهو الشيخ الإمام: إلكيا الهراسي أبو الحسن علي بن

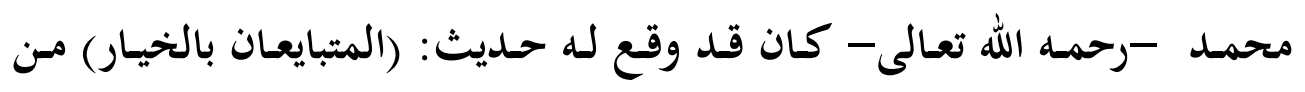

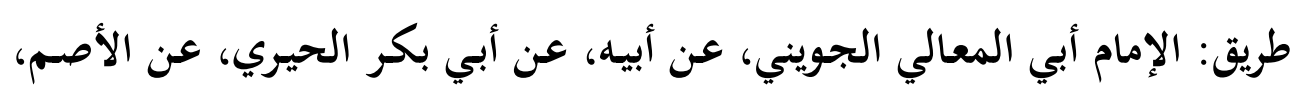

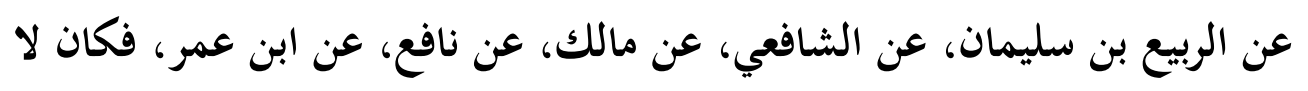

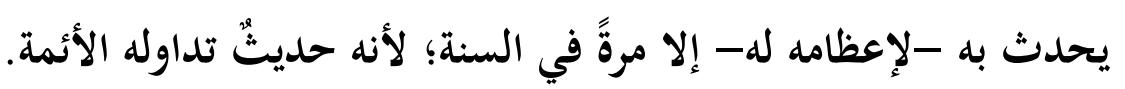

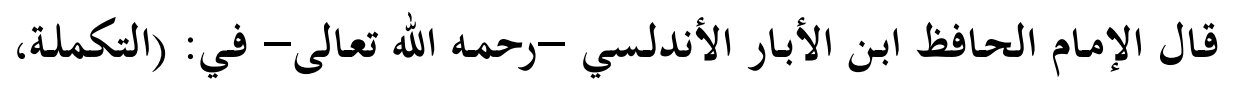

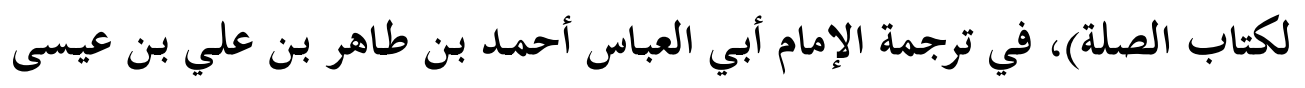

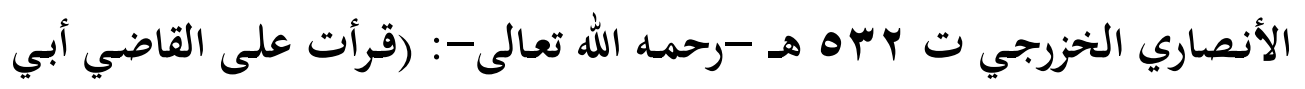

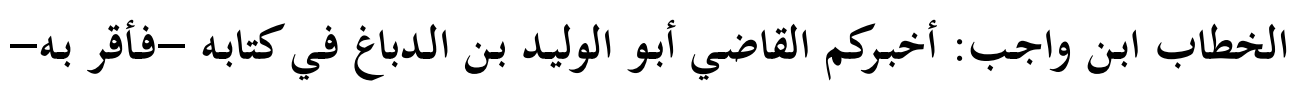

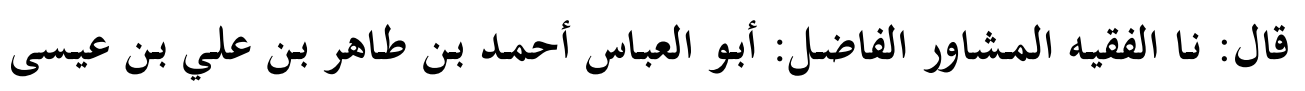

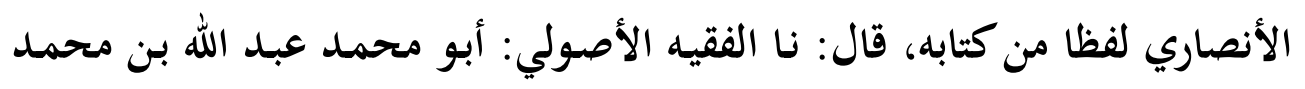
المقري قال: نا الشيخ الإمام أبو الحسن علي بن محمد -هو المعابه المعروف بكان بكيا- 
قال: وكان لا يحددث بـه إلا مرة في السنة لأنه حديث تداوله الأئمة، قال: أنا

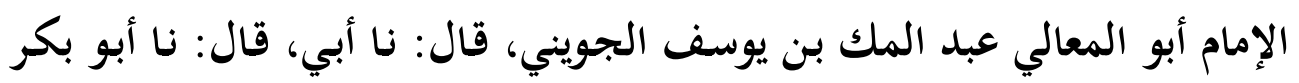

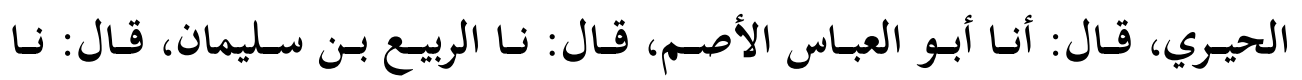

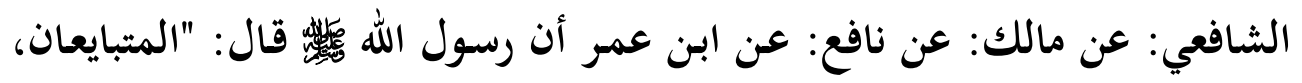

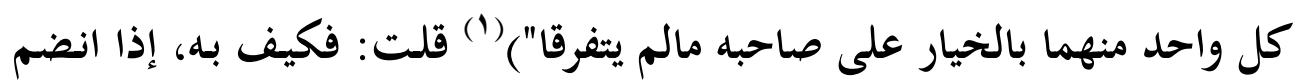

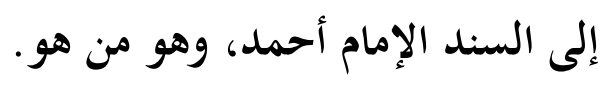

بل إن السند مع ضميمة أحمد يزداد فخامة وجزالة، لدرجة أن الإمام الحافظ

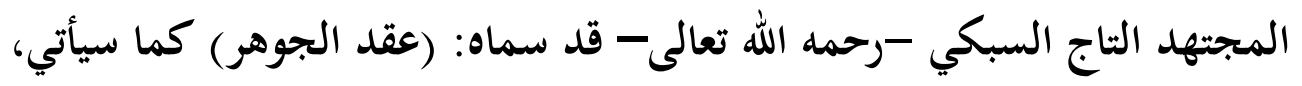
وقـال الحـافظ الـشمس الستخاوي في: (البلـدانيات): (وهـو حسديث شـريف؛ لاجتماع الأئمة الثلاثة فيه في نسق) (َ) لكـنْ في السند المـذكور لطيفـة أخسرى، وهـي أنسه مسلـسل بأكـابر فقهـاء الشافعية، الهراسي، والجويني، وأبيه، والحيري، والأصمى، والربيع، وهـم جهابذة

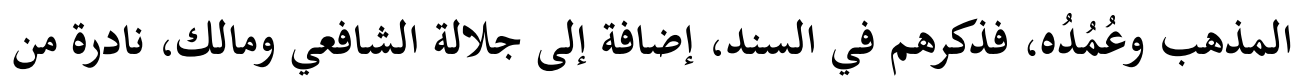
النوادر التي تشد إليها الرحال. حتى لقد أسنده من الطريق نفسه الحافظ الذهبي -رحمه الله تعالى - في ترجمة الإمام إلكيا الهراسي، وجعله مسلسلا بالفقهاء، قال في: (تاريخ الإسلام):

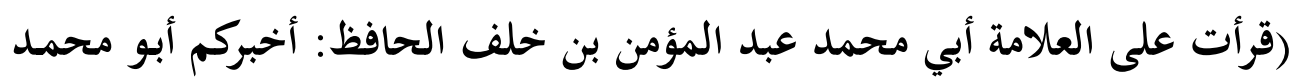

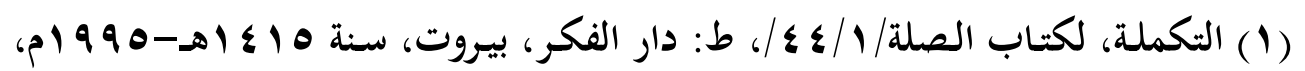
تحقيق: عبد السلام الهراس.

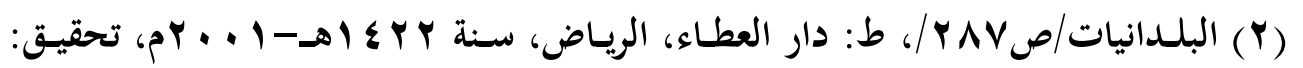
حسام محمد القطان. 
عبد العظيم بن عبد القوي الحافظ سنة تسع وثلاثين إملاء، أنه قرأ من حفظه على أبي الحسن علي بن المفضل الحافظ قال: ثنـا أبو طاهر بن سلفة الحسن الحافظ:

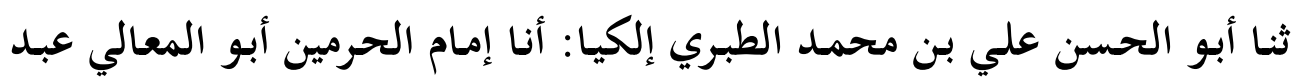

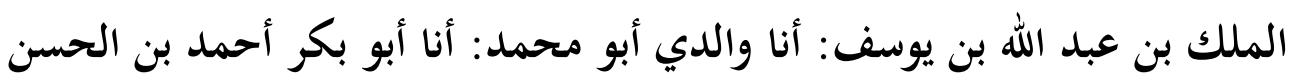

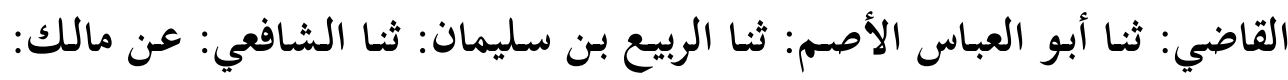

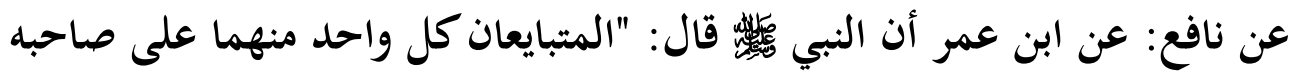

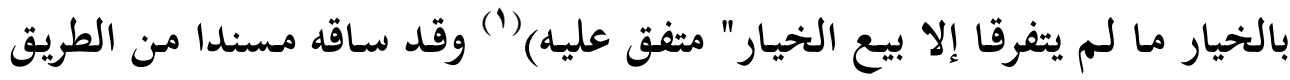

نفسه في: (سير أعلام النبلاء) ثم قال: (وهو مسلسل بالفقهاء إلى منتهاه) (؟ّ). قلـت : بـل ومـن المحـدثين مَنْ أفردَ المجـالسَ لإسـماع الأحاديـث المرويـة بهذا السند، ومنهم من أفردها بالتأليف، فممن أفرد المجالس لإسماعه الحافظ

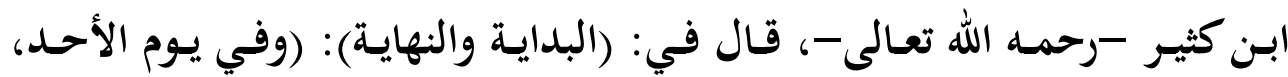

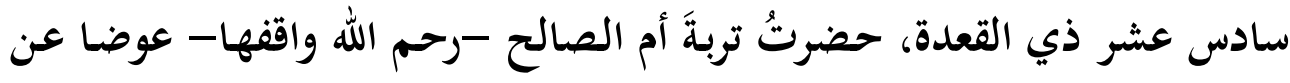
الشيخ شمس الدين الذهبي، وحضر جماعة من أعيان الفقهاء، وبعض القضاة،

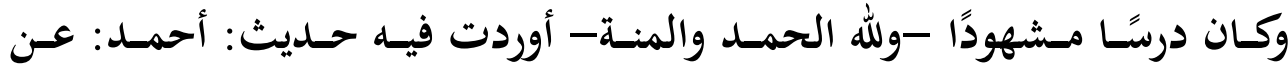
الشافعي: عن مالك: عن الزهري: عن عبدالرحمن بن كعب بن مالك: عن أبيه:

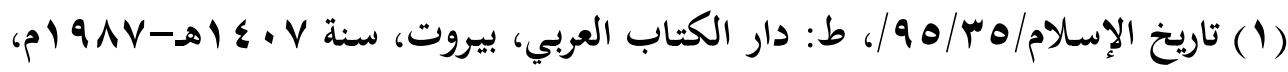
تحقيق: الدكتور عمر عبد السلام تدمري.

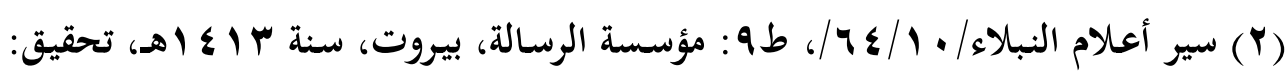
شعيب الأرناؤوط، ومحمد نعيم العرقسوسي. 


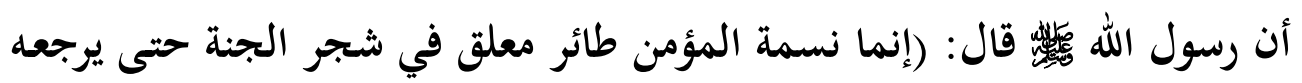

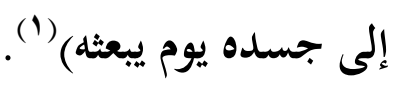

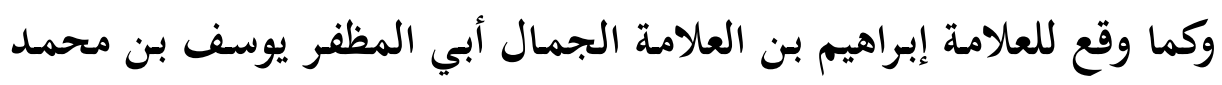

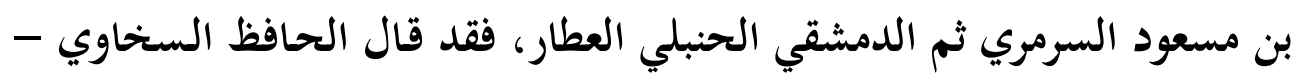

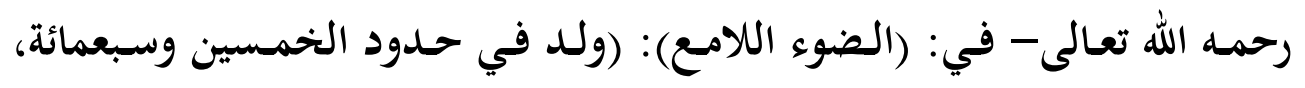
وأسمع على ابن الخباز جزءًا فيه أحاديث، رواها أحمد عن الشافعي، وفي آخره

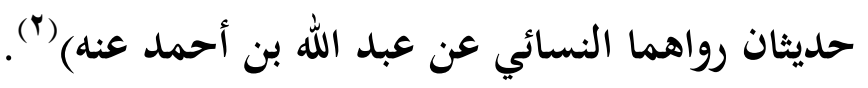

وكما فعل الحافظ السيد أبو الفيض محمد مرتضى الزبيدي رحمه الله تعالى،

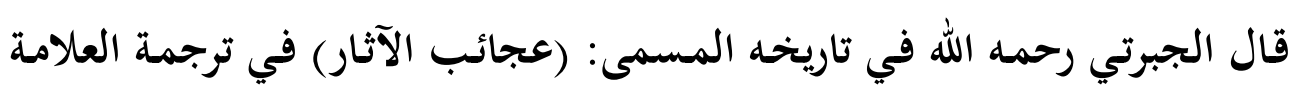

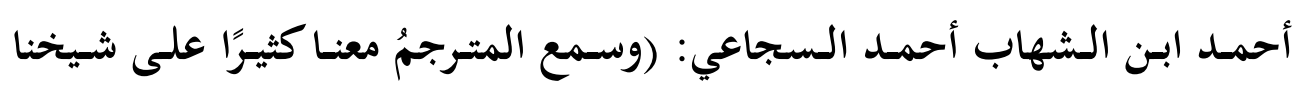

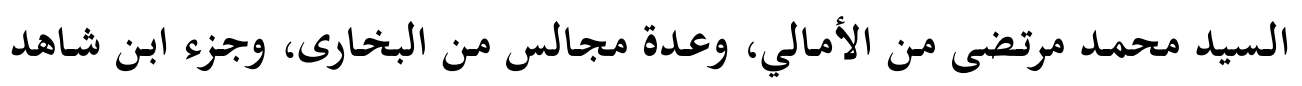

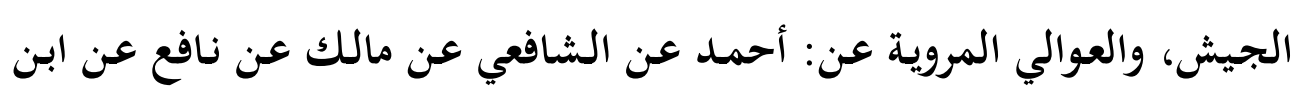
عمر، المسماة: بسلسلة الذهب، وغير ذلك) (بّ).

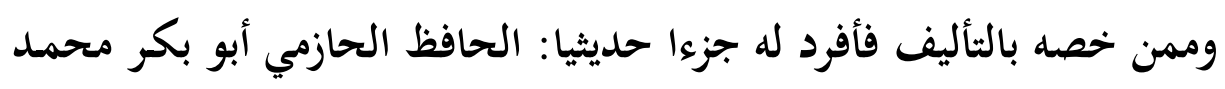
بن موسى بن عثمان بن حازم، صاحب كتاب: (شروط الأئمة)، فقد جمع تأليفا

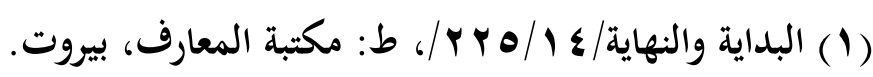

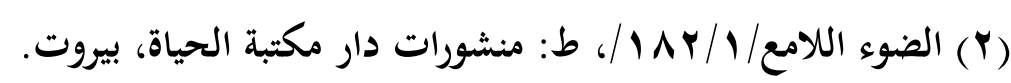

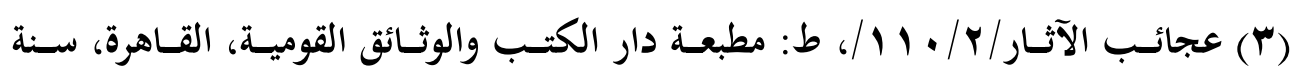

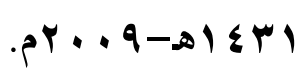


عنوانه: (كتاب سلسلة الذهب، فيما روى الإمام أحمد عن الشافعي)، قال عنه

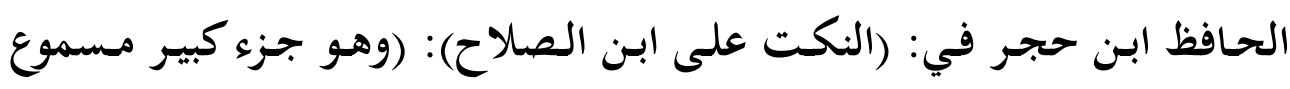

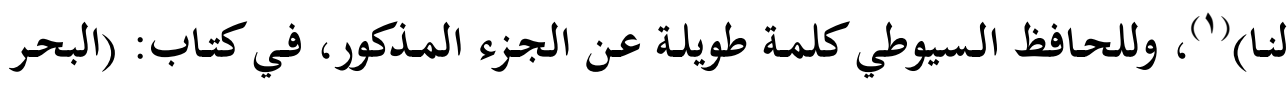
(الذي زخر)

وأشار الحافظ السخاوي في: (الضوء اللامع) إلى جزء في ما رواه الشافعي

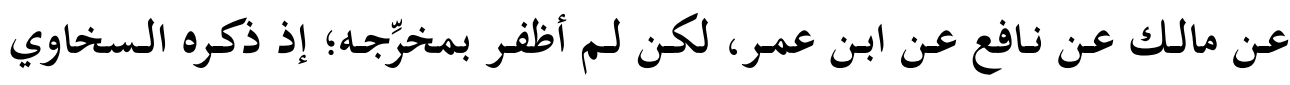

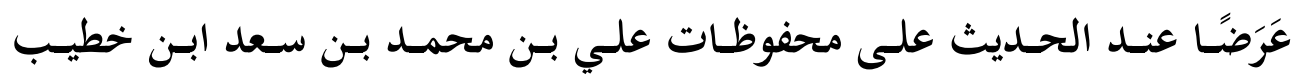
الناصرية، قال: (فحفظ القرآن، وكتبًا، منها المنهاج الفرعي، و"الأربعين المخرجة معند

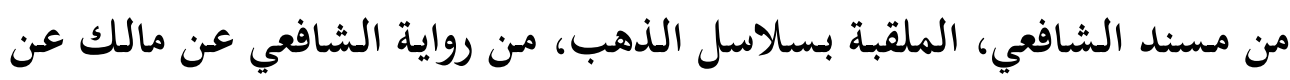

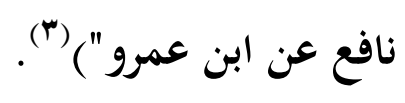

واعتنى الحافظ الجلال السيوطي بذلك، فأورد في الجزء المسمى بـ(الفانيد،

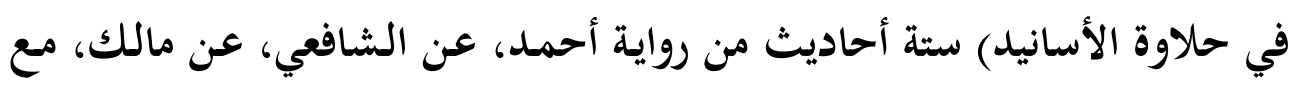

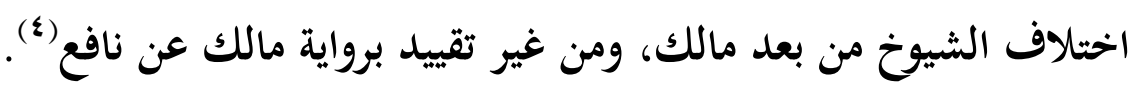

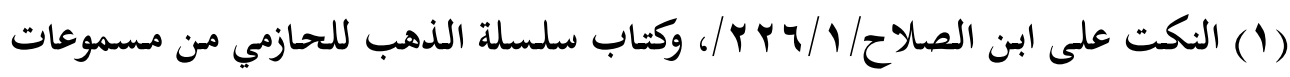

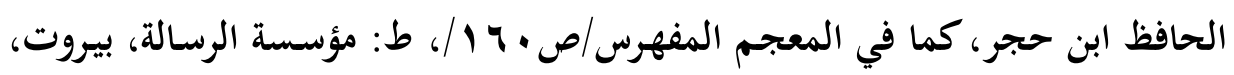

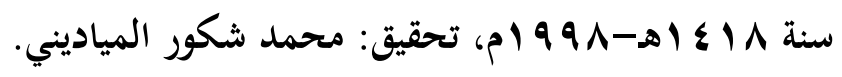

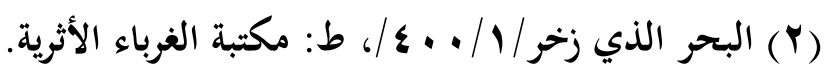

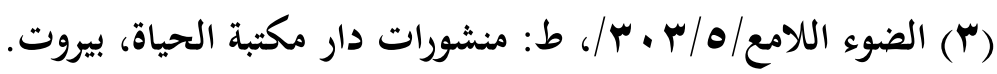

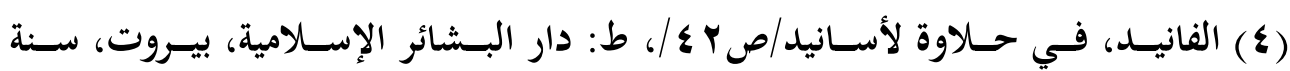
• 
=

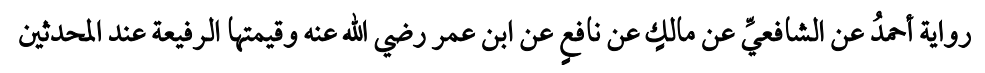

وانظر إلى مقدار حفاوة الزرقاني بسند اجتمع فيه أحمد والشافعي ومالك،

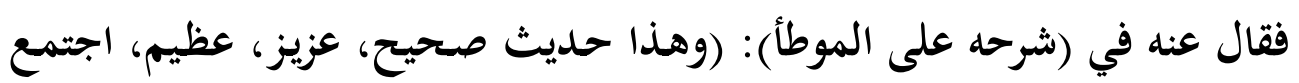

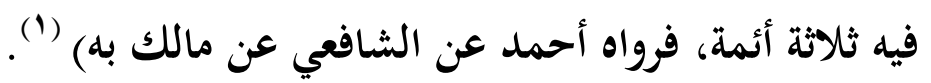

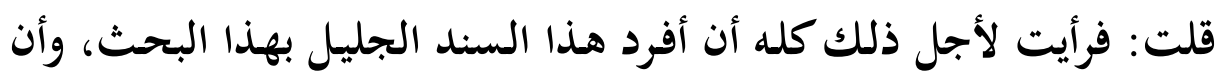

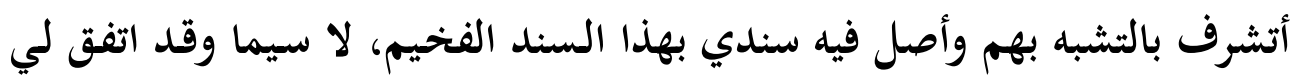

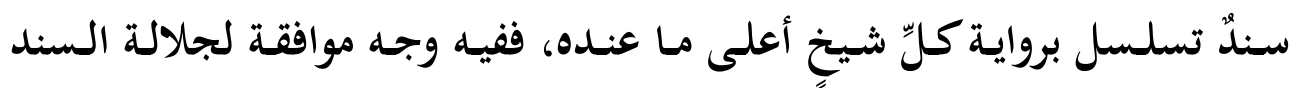
المذكور، مع بحوث لطيفة تتعلق بذلك السند الشريف، وبالله التوفيق.

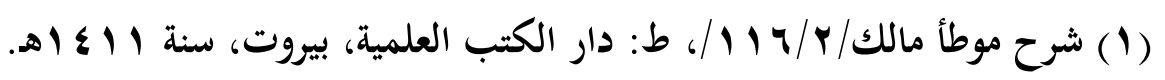




\section{المبحث الثاذي}

\section{أن الأصل في هذا السند هو اختيار الإمام}

البخاري أن ترجمة مالك عن نافع عن ابن عمر هي أصح الأسانيد

الأصل في هذا المبحث هو مسألة أصح الأسانيد، وقد مال الإمام البخاري

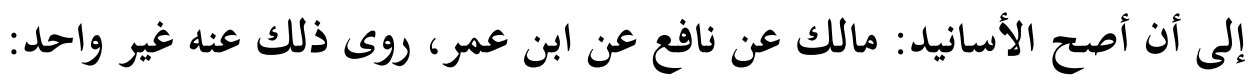

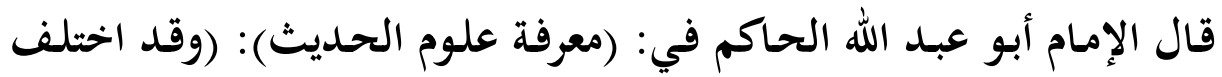

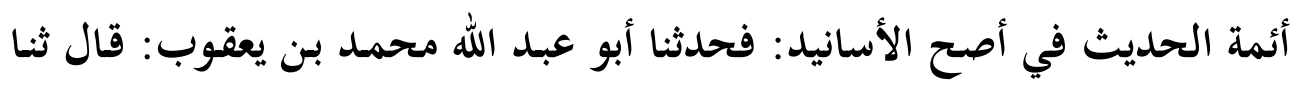
محمـد بـن سـليمان: قـال سـعت محمــد بـن إسـماعيل البخــاري يقـول: أصسح

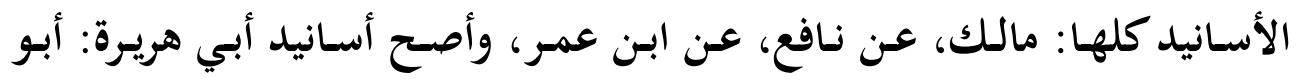
الزناد، عن الأعرج، عن أبي هريرة) (1).

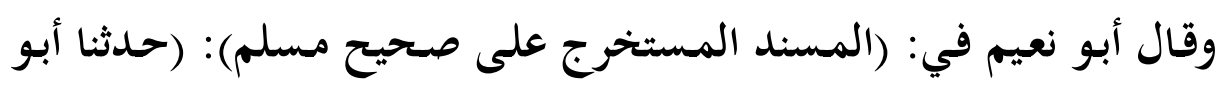

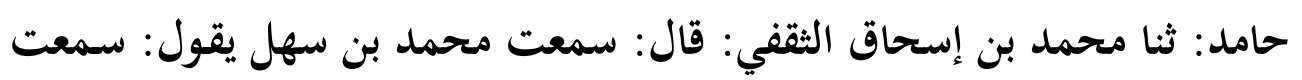

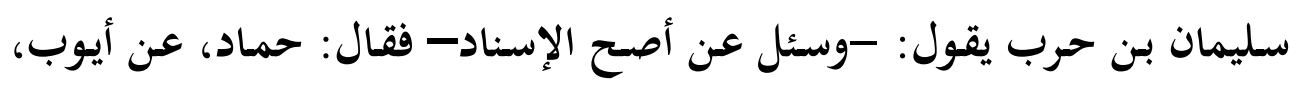
عن محمد عن عبيدة، عن علي.

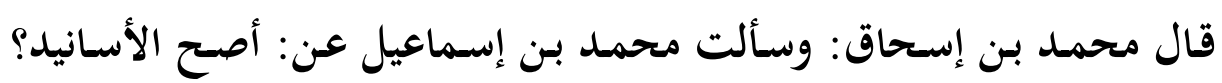

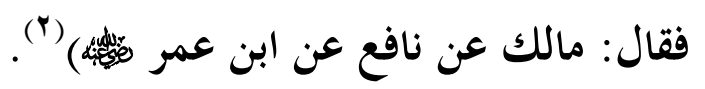

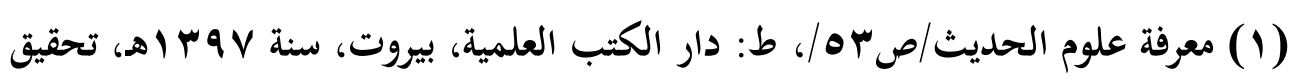
السيد معظم حسين.

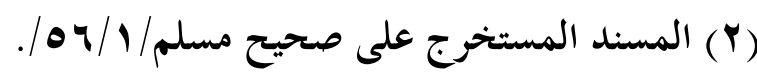
IIVT 
وقال البيهقي في: (السنن الكبرى): (أخبرنا أبو عبد الله الحافظ: أنبأ أبو

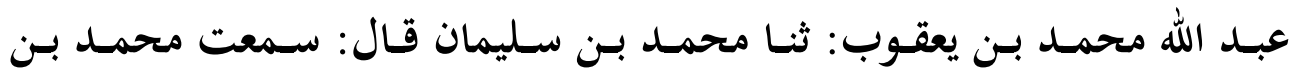

إسماعيل البخاري يقول: أصح الأسانيد كلها مالك عن نافع عن بن عمر.

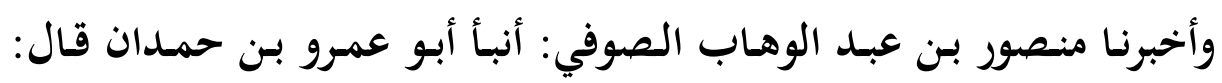

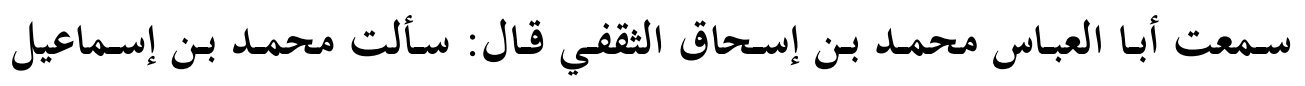

البخاري عن أصح الأسانيد؟ فقال: مالك عن نافع عن بن عمر ) (1).

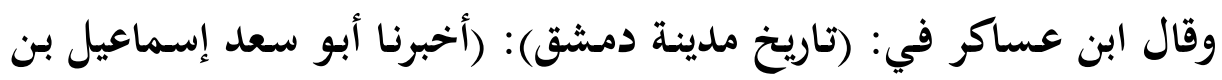

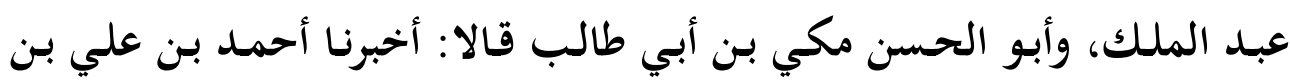

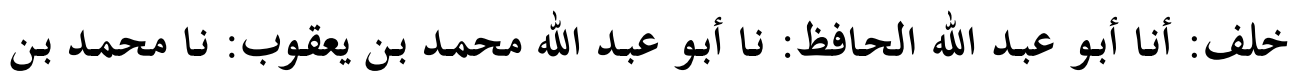

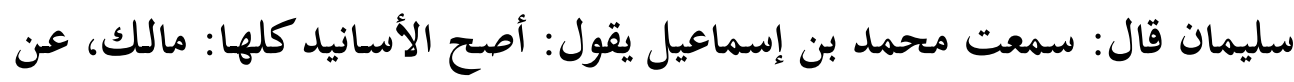

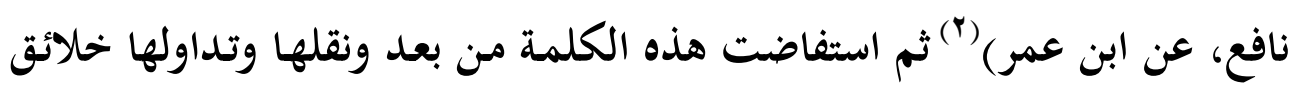

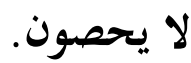

وقال الحافظ السيوطي في: (تدريب الراوي): (وهذا قول البخاري، وصدر

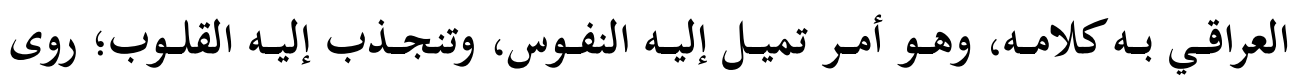
الخطيب في: (الكفاية) عن: يحيى بن بكر أنه قال لأبي زرعة الرازي: "يا أبـا

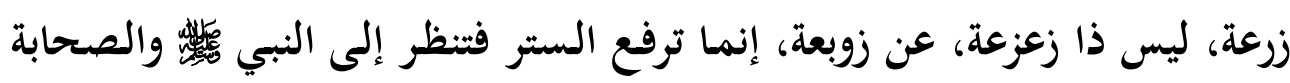
"و

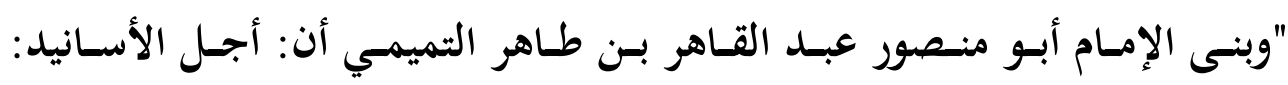

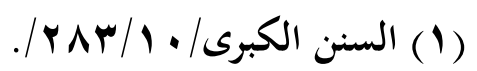

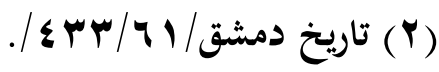


"الشافعي، عن مالك، عن نافع، عن ابن عمر"، واحتج بإجماع أهل الحـديث

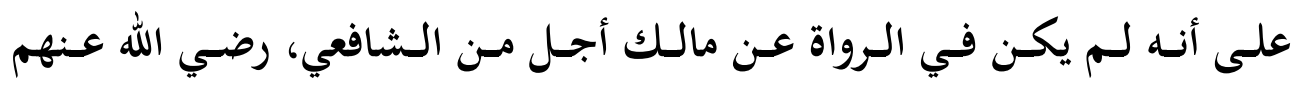
(1) أجمعين)

قلت: هذا وقد أطلق البخاري القول في السند المذكور أنه أصح الأسانيد، لكن نقل الحاكم عنه أنه أصح أسانيد ابن عمر، قال الحافظ العراقي في (طرح

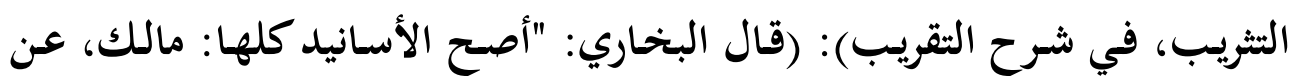

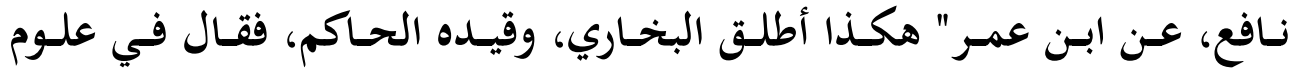
الحديث: أصح أسانيد ابن عمر: مالك، عن نافع، عن ابن عمر) (َ). وأقول: الخلاف هنا في المنقول عن البخاري، لا في أصل مسألة أصح الأسانيد، فِإن الخلاف فيها منتشر مشهور، لكن نحن هنا بصدد تحرير القول المنقول عن الإمام البخاري في المسألة، والذي نقله عنه الحاكم في معرفة علوم

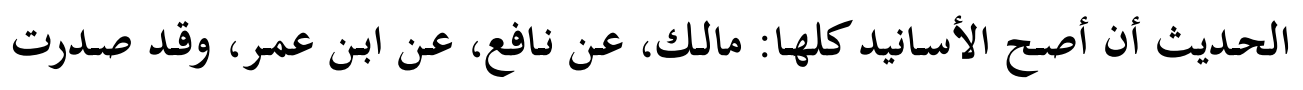

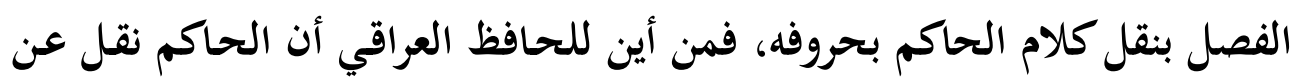

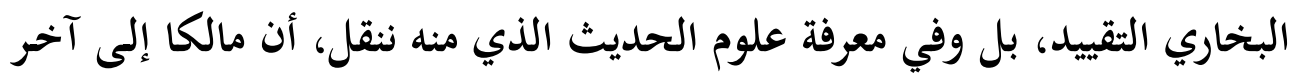
السلسلة هو أصح أسانيد ابن عمر هكذا مقيدا، فالله أعلم بحقيقة الحال.

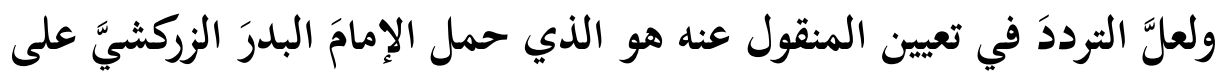

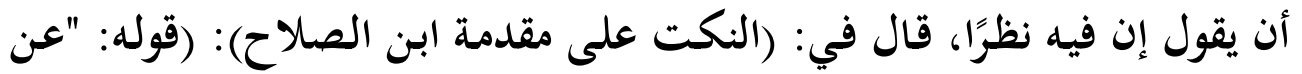

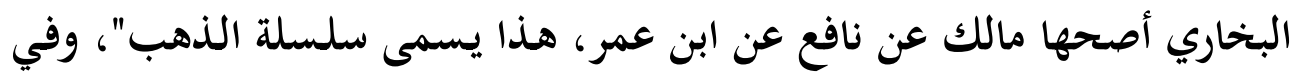

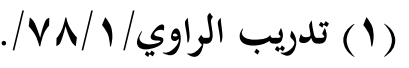

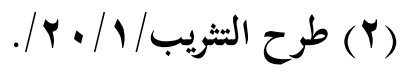


هذا الإطلاق عنه نظرٌ؛ ففي "ذم الكلام" للهروي: قال الراوساني: قال محمد بن

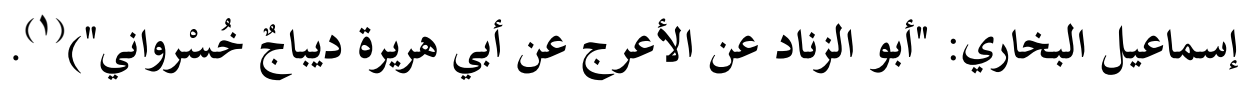
والنص الذي يشير إليه الإمام الزركشي في كتاب: (ذم الكالام وأهله) لأبي الني

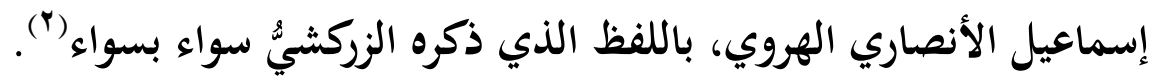

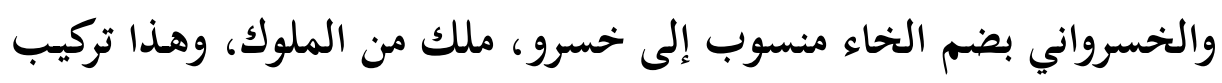

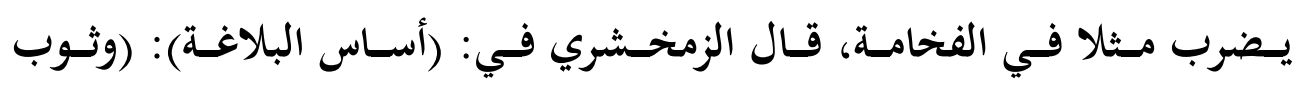

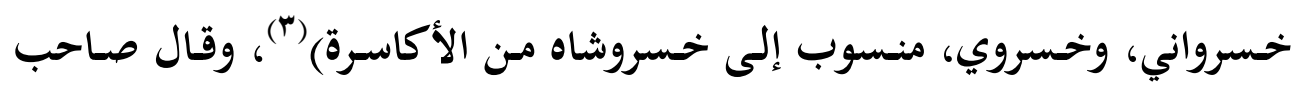

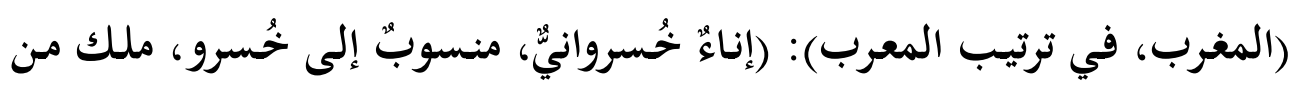

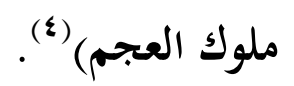
قلت: ويقال: إناءُ خُسْرَوانيُّ، وشراب خسرواني، ودرهم خسرواني، كما رأيته مفرقا في عيون كتب اللغة، مثل (تهذيب اللغة)، و (المحكم)، و (لسان العرب)، و(تاج العروس)، و(يتيمة الدهر)، فليتتبعه من شاء. وقد وقع هذا الوصف المنيف في الحديث الشريف، وجاء وصفًا لجبة سيدنا

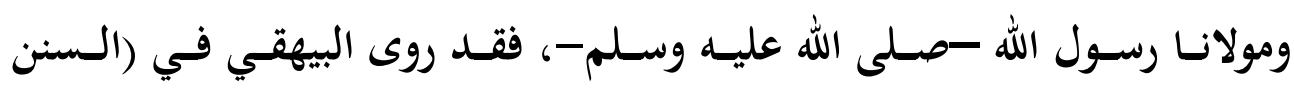
الكبرى) من حديث طويل: (فذهب إلى أسماء فأخبرها، قال عبد الله -يعني: ابن اله

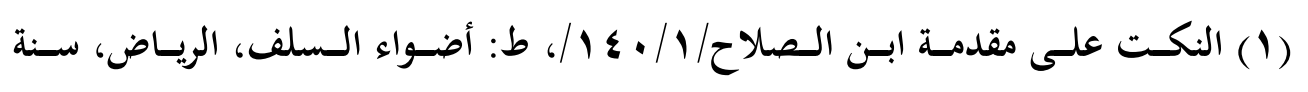

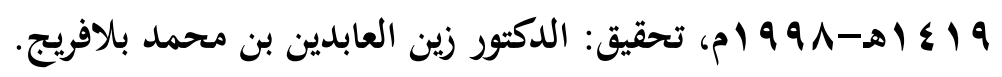

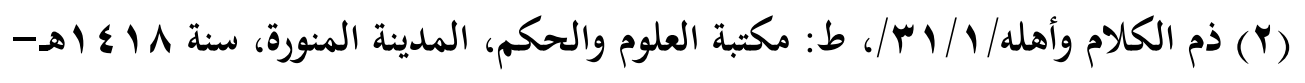

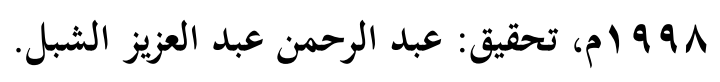

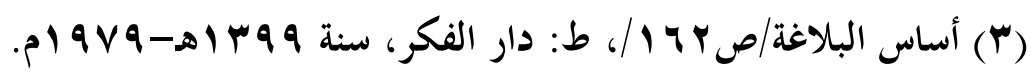

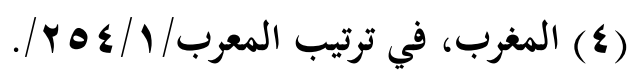




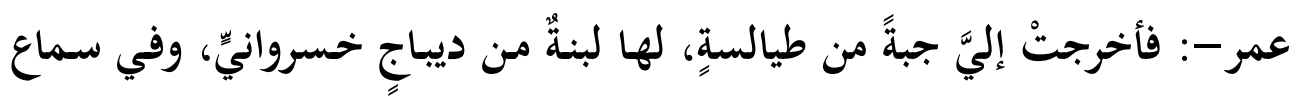

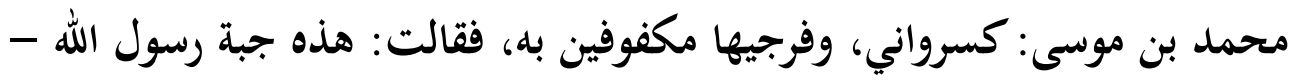

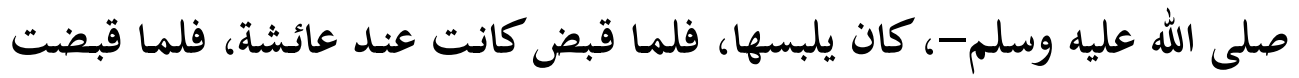

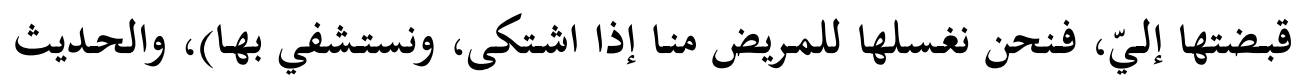
في صحيح مسلم بلفظ: (كسرواني) (').

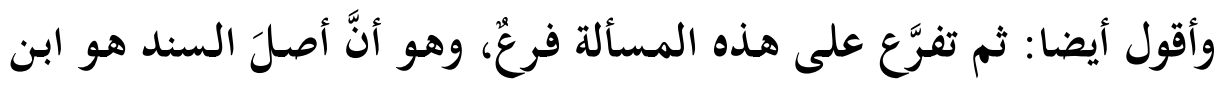

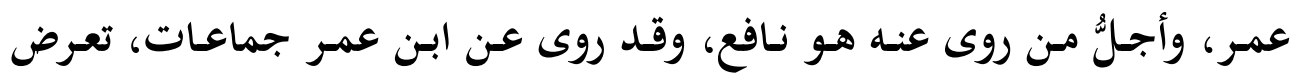

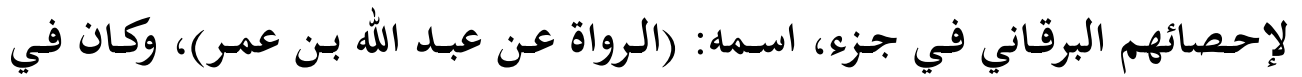

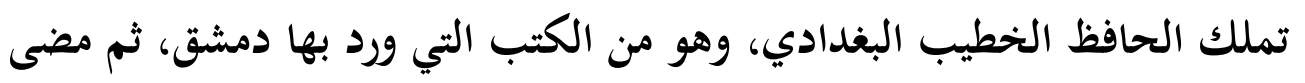

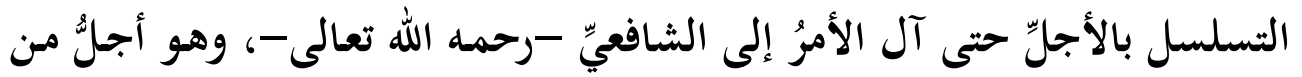

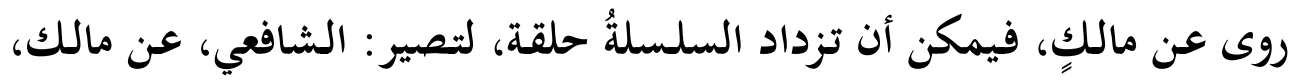
عن نـافع، عـن ابـن عمر، وهـو تفريـع جيـد لأبي منـصور عبـد القـاهر بـن طـاهر

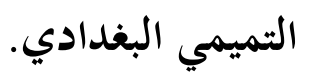
قال الحـافظُ أبو عمرو ابـ الصلاح -رحمـه الله تعالى - في: (المقدمـة):

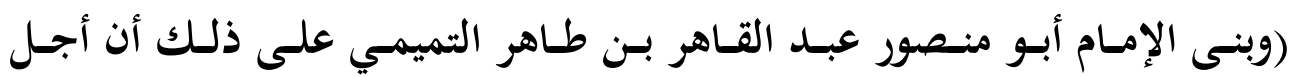

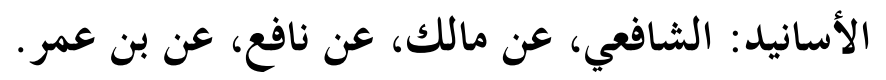

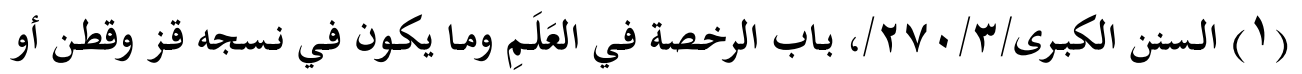

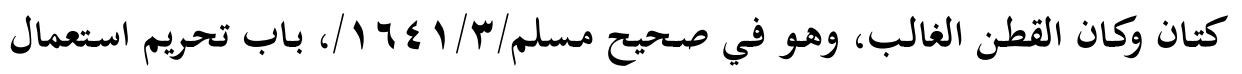
إناء الذهب والفضة على الرجال والنساء وخاتم الذهب والحرير على الرجل وإباحته

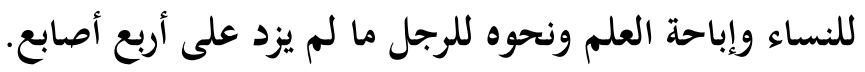


واحتج بإجماع أصحاب الحديث على أنه لم يكن في الرواة عن مالك أجل

من الشافعي رضي الله عنهم أجمعين والله أعلم)('.

قلت : وقد نوزع أبو منصور في دعواه، وناقشه فيها المالكية والأحناف

مناقشات مطولة، واحتج له أناس بأمور تعضد دعواه.

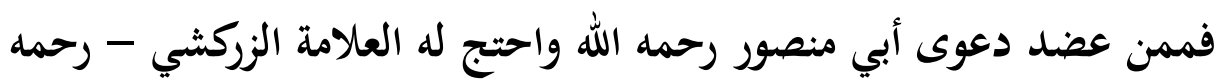

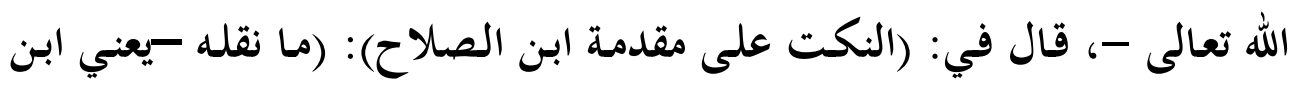

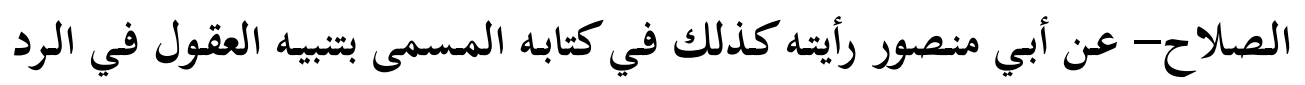

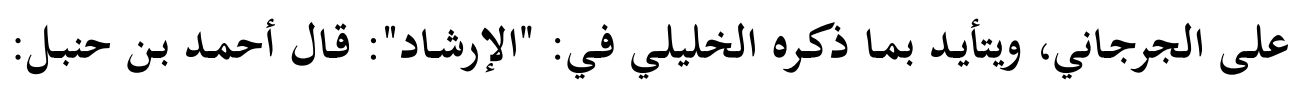

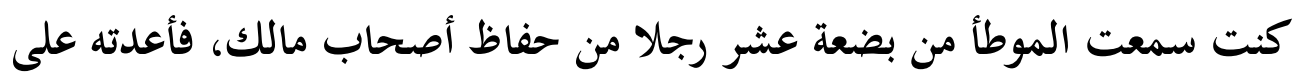
الشافعي؛ لأني وجدته أقومهم به.

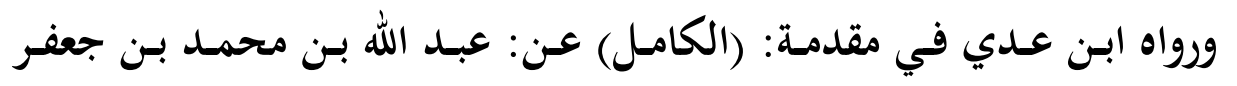
القزويني: ثنا صالح بن أحمد بن حنبل قال: سمعت أبي يقول: سمعت الموطأ

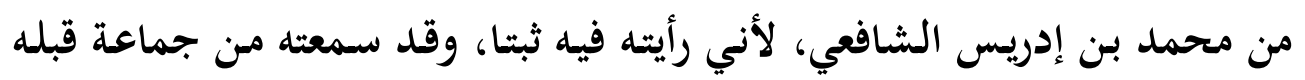
انتهى، وهذا تصريح من أحمد بأن من أجل من روى عن مالك هو الشافعي) (َ).

ولهذا السند نظير عند المتأخرين، حيث وقع لمسند الدنيا الإمـام العلامـة

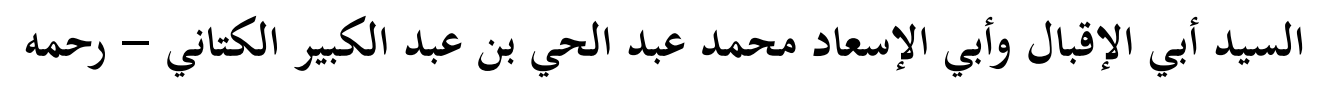

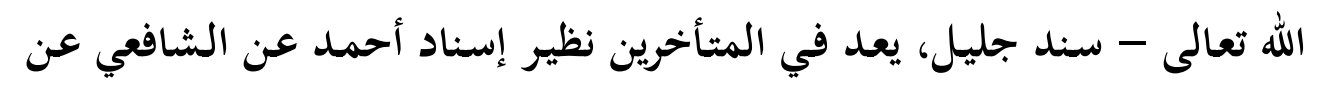

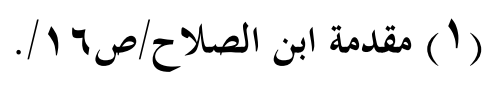

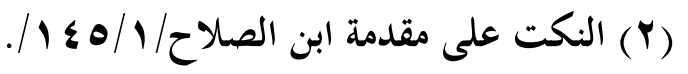




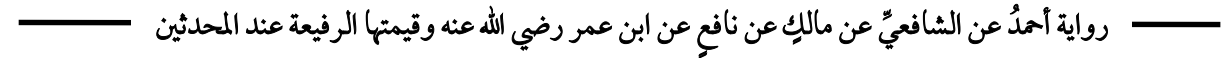

مالك في المتقدمين، وهو ما يرويه عن أبيه، عن العلامة عبد الغني بن أبي سعيد

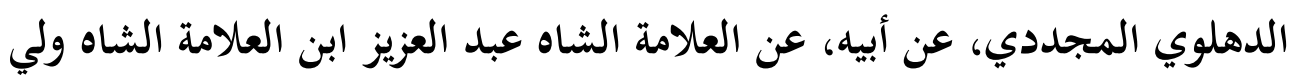

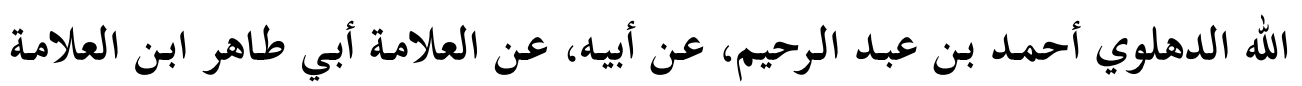

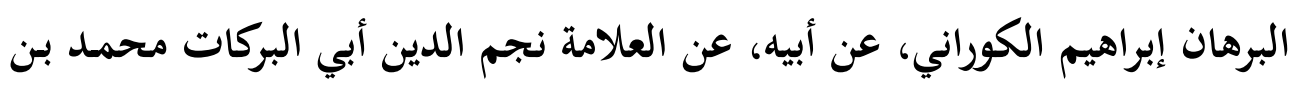

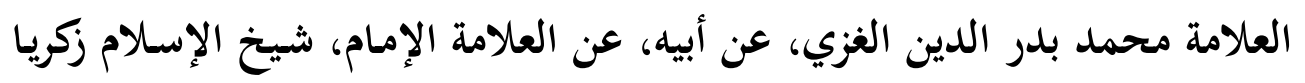
الأنصاري، عن الحافظ ابن حجر .

قال -رحمه الله تعالى- في: (فهرس الفهارس والأثبات): (لا أتقنَ ولا أوثقَ في سلاسل المتأخرين من هذه السلسلة؛ لأنها مع علوها مسلسلةٌ بأيمة الأعصار

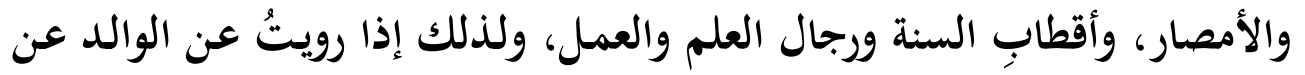

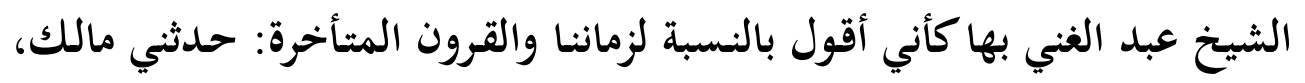

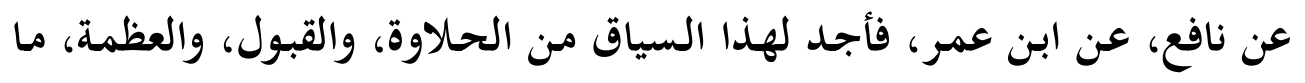

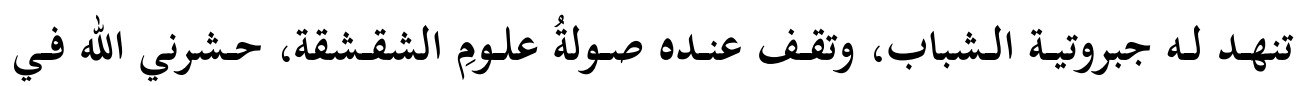
زمرتهم، وألحقني بهم مع الرعيل الأول، من السابقين الأولين) ('). وأنـا أروي هـذا الإسـناد من طريق شيخنا السيد عبد الرحمن بـن الإمـام السيد محمد عبد الحي بن عبد الكبير الكتاني، والسيد أحمد بن أبي بكر

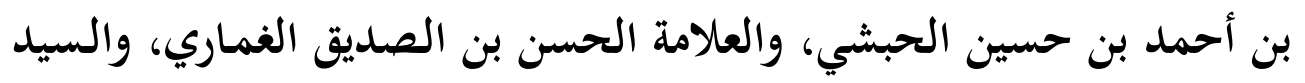
إدريس بـن محمد الماحي بن عبد الكبير الكتاني، أربعتهم عن والد الأول وعم الأخير السيد محمد عبد الحي الكتاني بسنده المذكور.

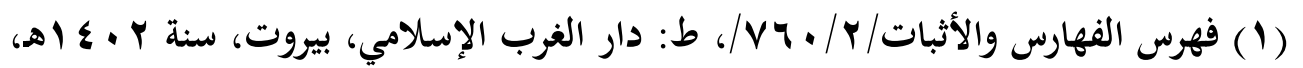
تحقيق: إحسان عباس. 


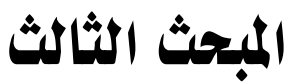

في إمكان الزيادة على ترجمة مالك عن

نافع عن ابن عمر من جنسها، وتحول سلسلة الذهب إلى عقد

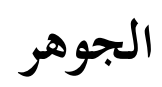

ثم إنه قد انبنى على هذا الأصل بحث آخر، وهو إمكان الزيادة في هذا

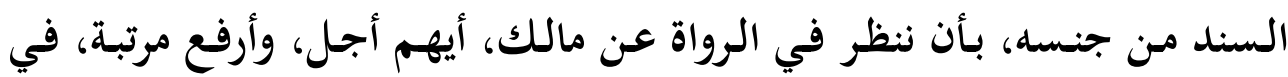

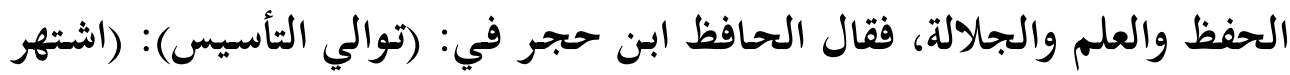

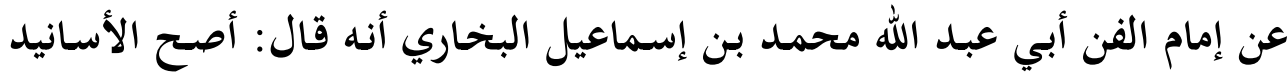
كلها: مالك، عن نافع، عن ابن عمر.

فجاء من بعده فقال: ينبغي أن يضم إلى هذه الترجمة: الشافعي، لإطباقهم

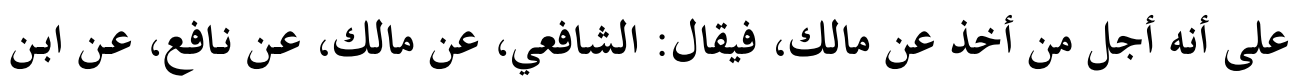

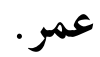

ثم جاء بعض المتأخرين من شيوخ شيوخنا، وتبعه جماعة من شيوخنا فقالوا:

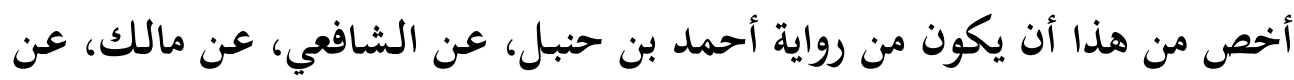

$$
\text { نافع، عن ابن عمر)('. }
$$

وقال ابن حجر في: (النكت على ابن الصلاح): (وعلى تسليم ما ذكره أبو ألما

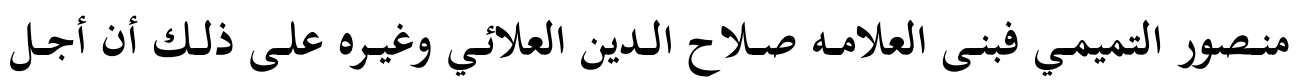

(1) توالي التأسيس/ص19/1. 
الأسانيد رواية أحمد بن حنبل عن الشافعي عن مالك عن نافع عن ابن عمر رضي

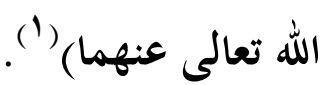

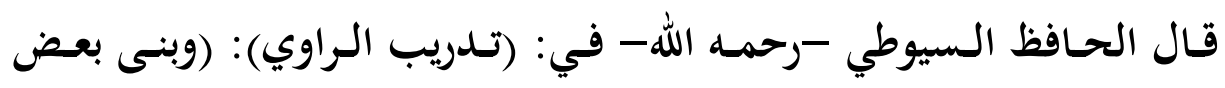

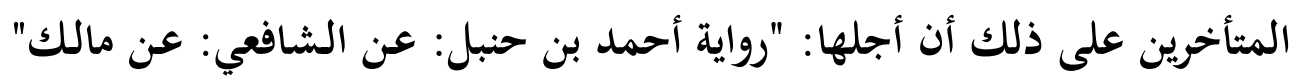

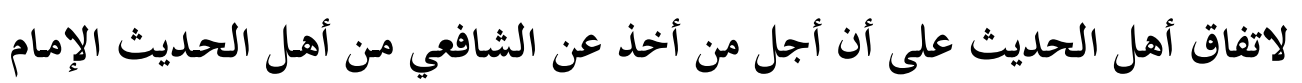
أحمد.

وتسمى هذه الترجمة: "سلسلة الذهب"، وليس في مسنده - على كبره -

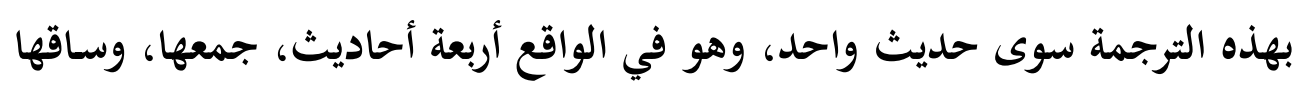

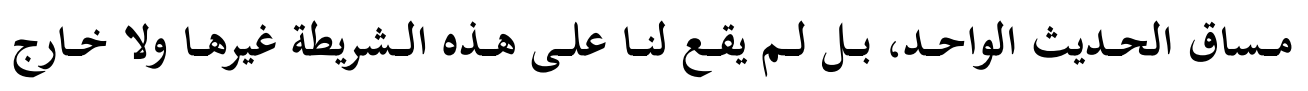

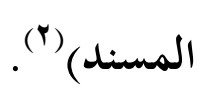

قلت: وحيث قد امثد السند وكمل بهذه الترجمة، فقد ازداد جلالة، حتى لقد

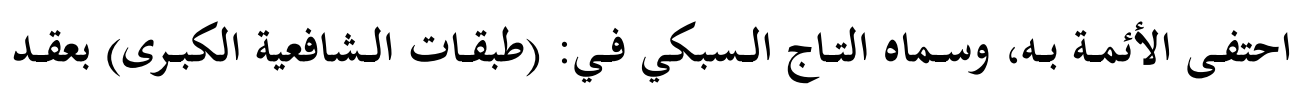

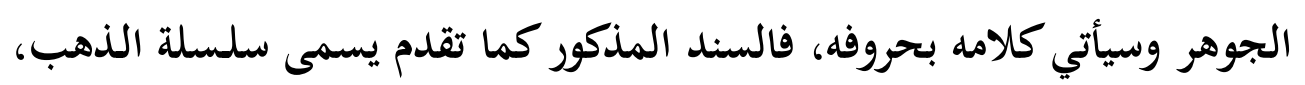
وهو بضميمة الإمام الشافعي والإمام أحمد يسمى عقد الجوهر .

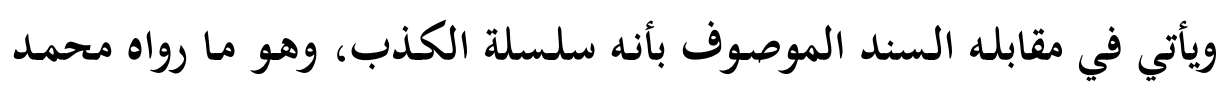

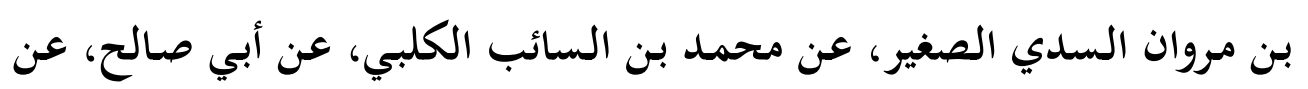

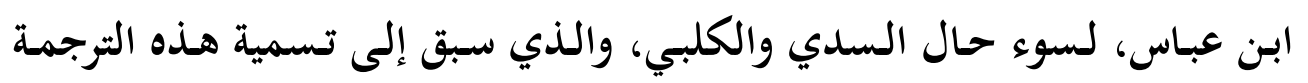

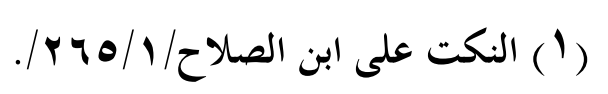

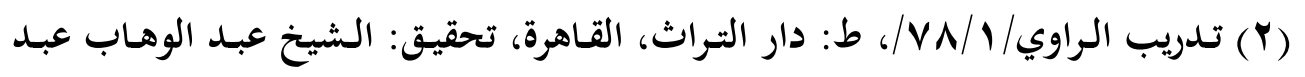


بسلسلة الكذب هو الحافظ ابن حجر رحمه الله، قال في: (العجاب في بيان

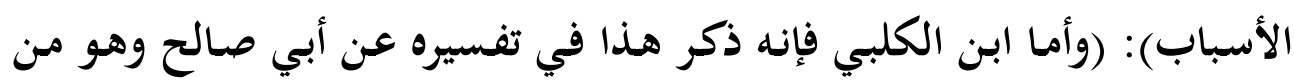

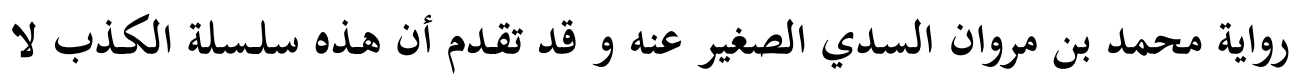
سلسلة الذهب) (1). ومشى على هذا الاصطلاح من بعد جماعة من الحفاظ، منهم السيوطي في:

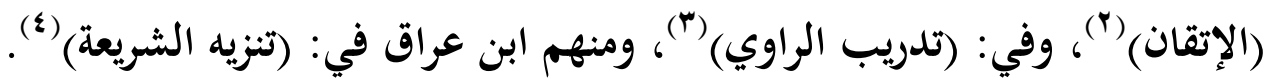

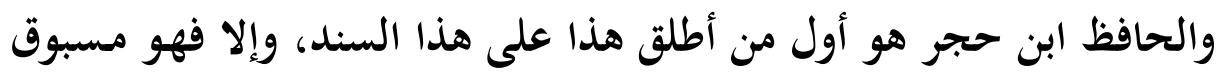

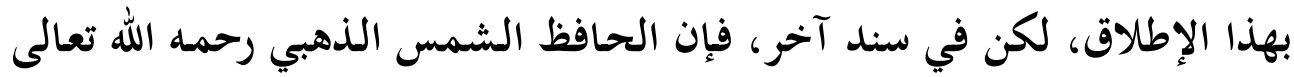
قد قال عن سند فيه: الكاشغري، والطيبي، وابن محلى: هو سلسلة الكذب، فقد إلى

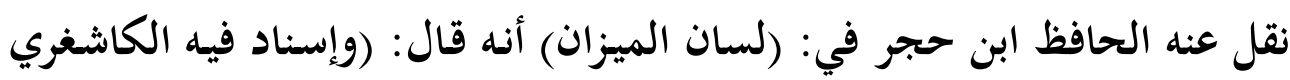

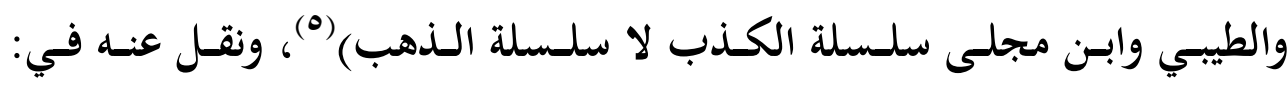

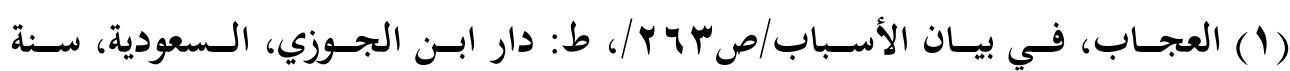

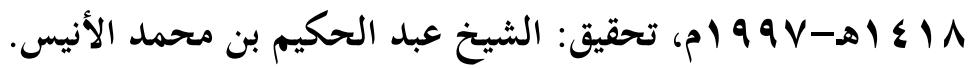

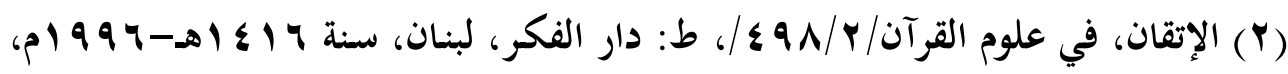
تحقيق: سعيد المندوب.

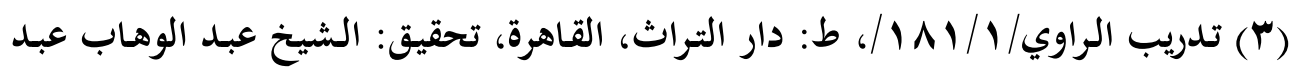
اللطيف.

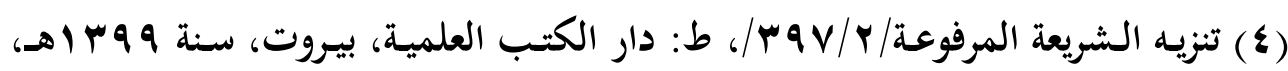

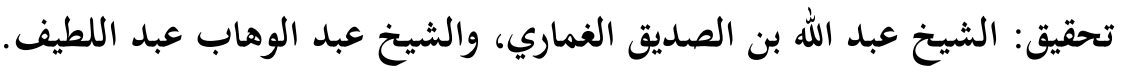

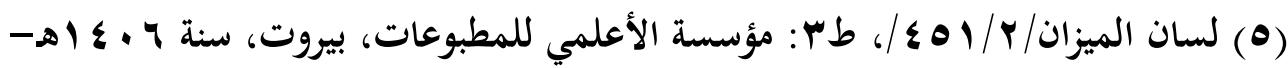


(الإصابة) قوله: (وإسناد فيه هذا الكاشغري، والطيبي، وموسى بن مجلي، ورتن،

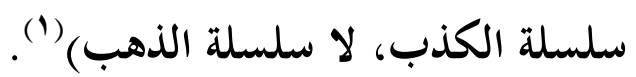

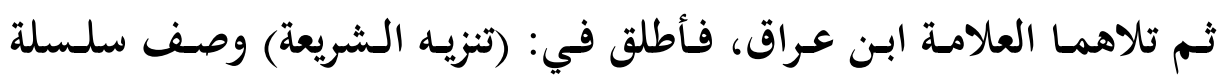

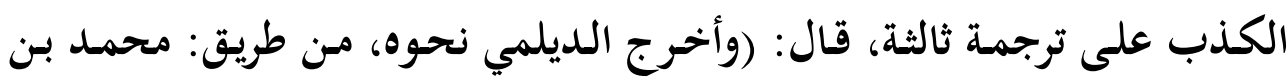

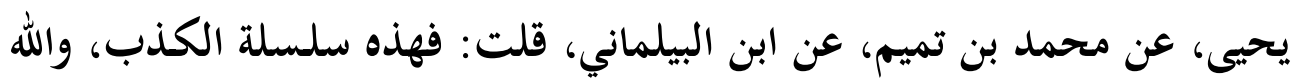

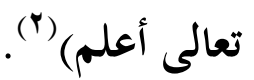
فهذه عدة إطلاقات لوصف سلسلة الكذب، على عدد من التراجم وسلاسل الأسانيد، بعضها أسوأ حالا من بعض، والله تعالى أعلم.

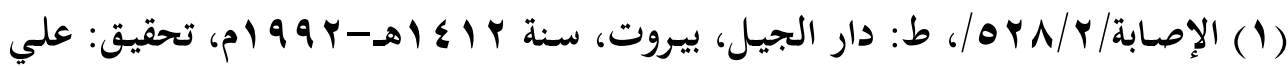

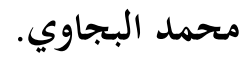

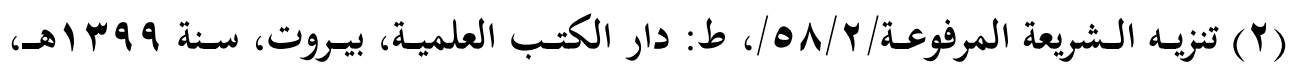

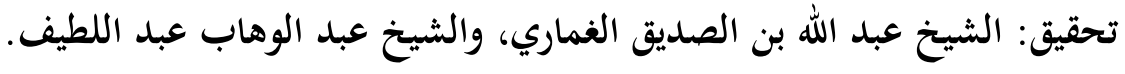




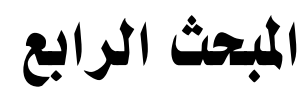

في استقرار سلسلة عقد الجوهر ونهوض الحفاظ الماظ

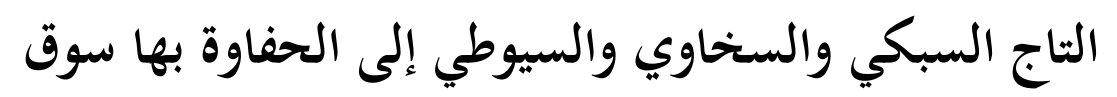

أسانيدهم إليها

وقد أسند الحافظ المجتهد التاج السبكي -رحمه الله تعالى- في: (طبقات الشافعية الكبرى) السند المسسمى: (عقد الجوهر)، قال: (أخبرنـا الحـافظ أبو الهو

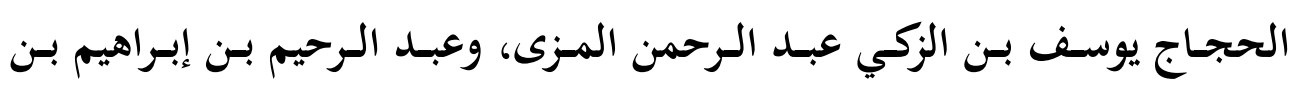

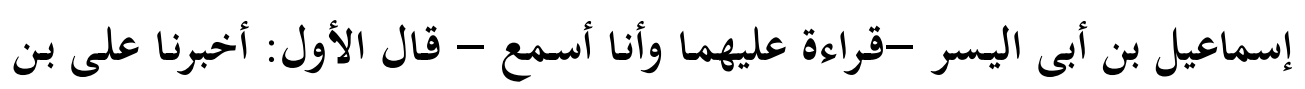

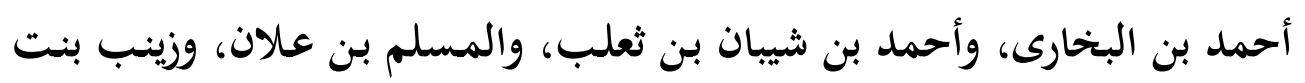

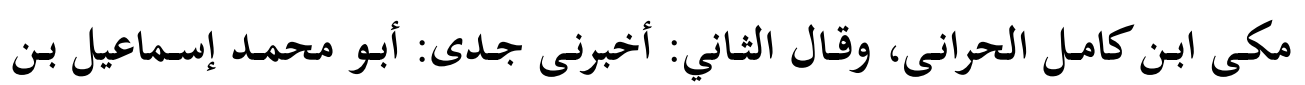

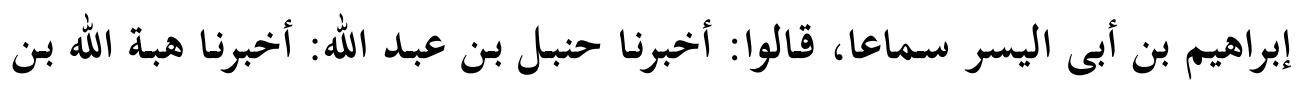
محمد) بسنده المذكور آنفا.

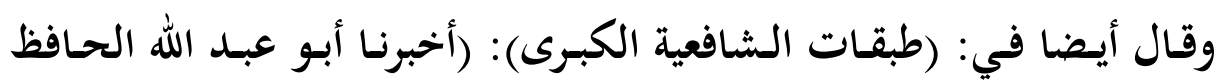

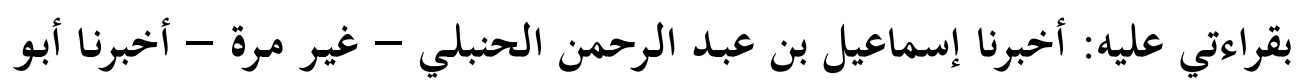

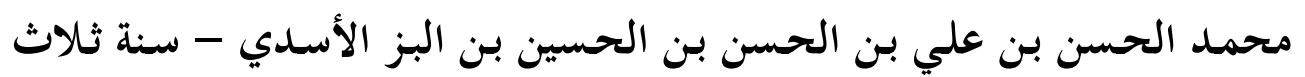

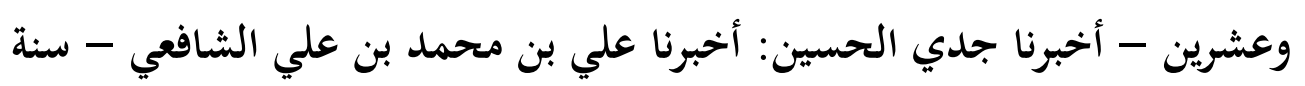

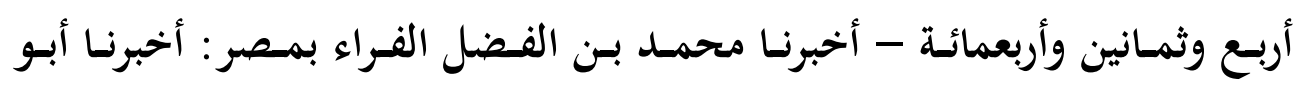

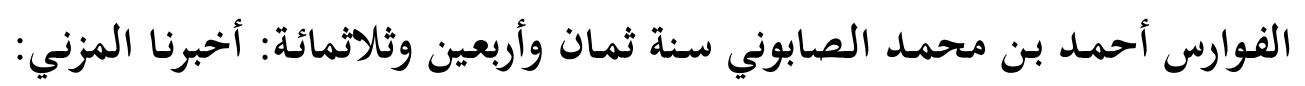




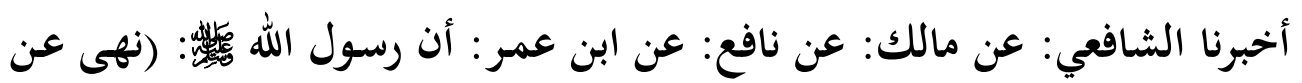
الوصال، فقيل: إنك تواصل!! فقال: لست مثلكم، مان إني أطعم وأسقى).

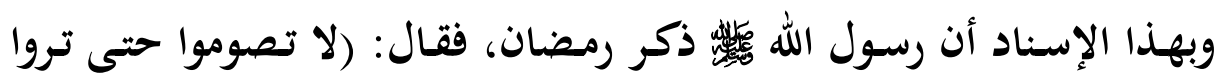
الهلال، ولا تفطروا حتى تروه، فإن غم عليكم فاقدروا له).

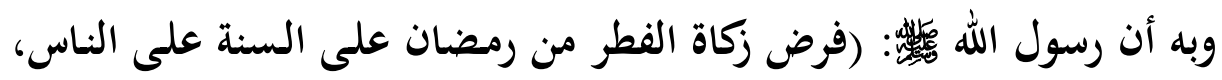

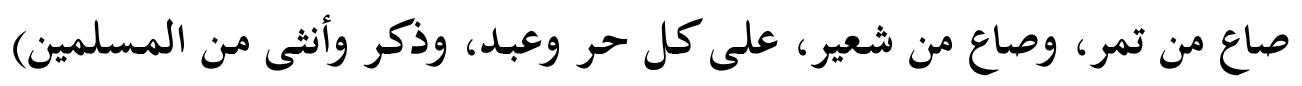
متفق عليها، وهى من الأسانيد التي ينبغي أن تسمى عقد الجوهر ولا حرج.

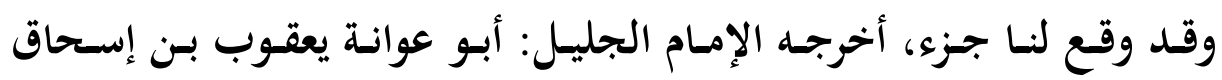
الإسفراينى، فيه ما في مختصر أبى إبراهيم المزني من الأحاديث بالأسانيد، أخبرنا

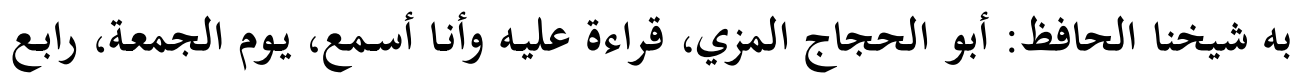

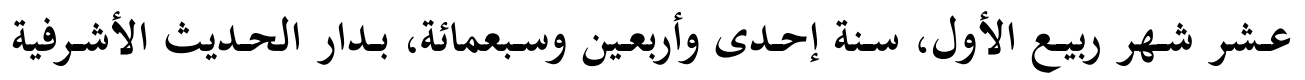

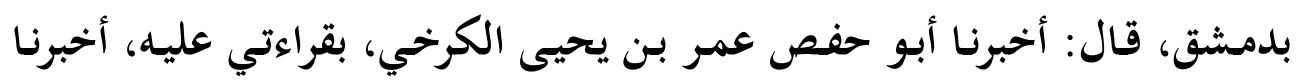
الحافظ أبو عمرو ابن الصلاح.

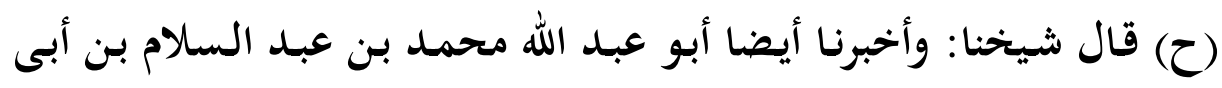

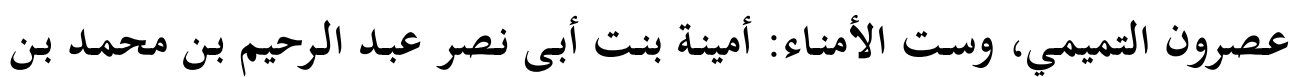

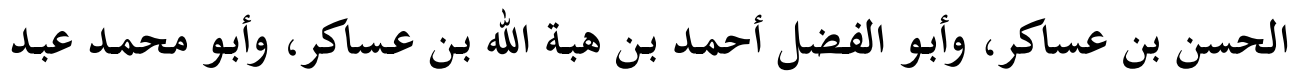

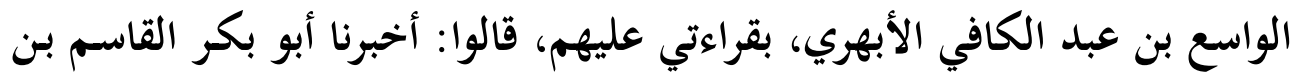

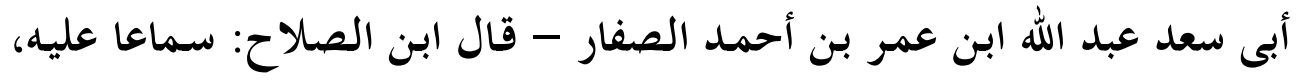

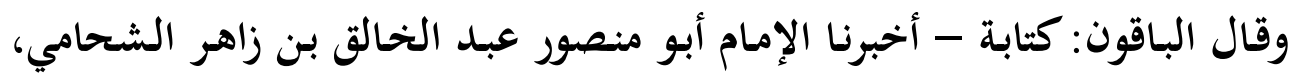

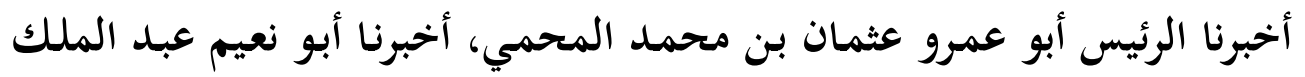

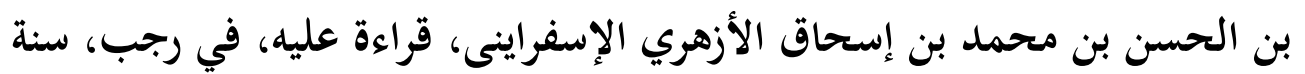




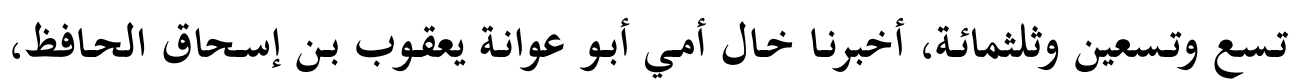

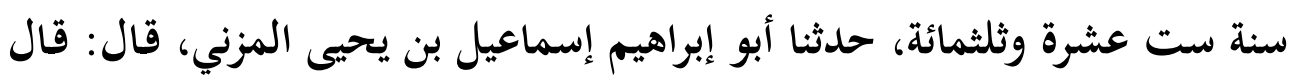

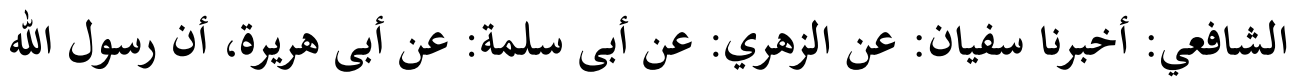
إل ثلاثا، فِإنه لا يدرى أين باتت يده).

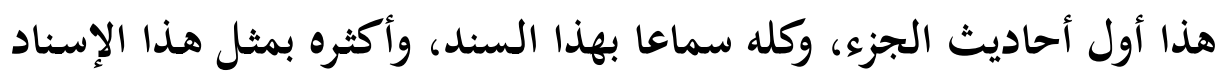
العظيم، فمـ أبى نعيم إلى أبى هريرة كلهم أئمة أجحلاء، ثمانيـة مـ السادات: علما، ودينا، وإتقانا) (1)، انتهى كلام السبكي بحروفه، وهو على طولى طوله نفيس.

وأســنده الحـافظ الـشمس الـسـخاوي -رحمـهـ الله تعـالى - فـي جــزء: (البلدانيات) له، قال: (البلد السادس والسبعون: منية نابت -بنون، ثم موحدة، بعدها مثناة فوقانية، على شاطئ النيل من الغربية، قريبة من جوجر - : أخبرني العز

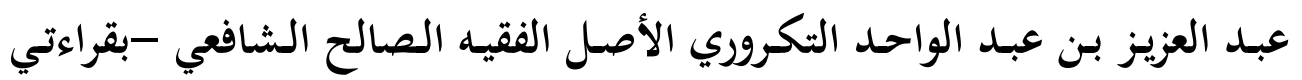

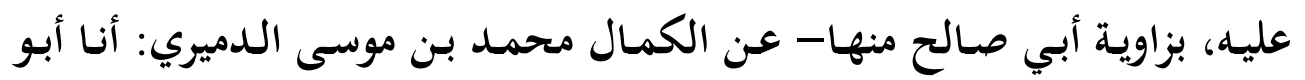
الحسن علي بن أحمد العرضي.

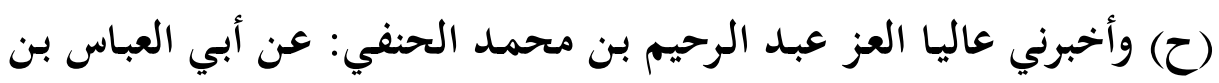

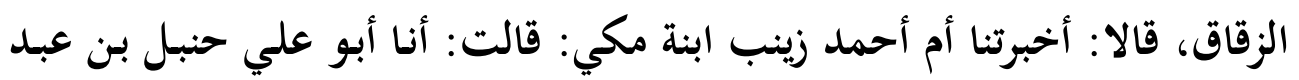
الله: أنا أبو القاسم بن الحصين: أنا أبو علي التميمي: أنا أبو بكر القطيعي: ثنا

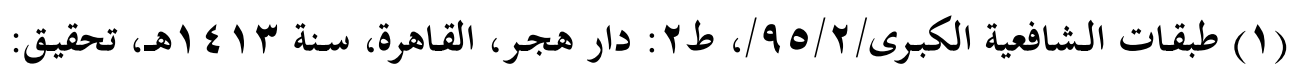

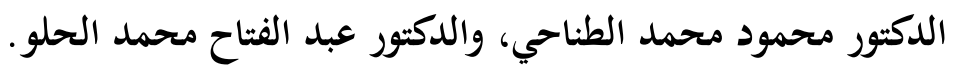




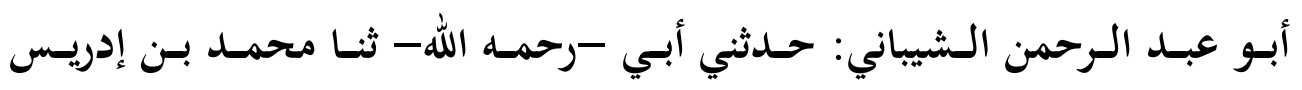

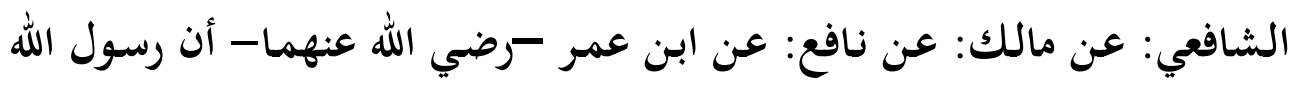

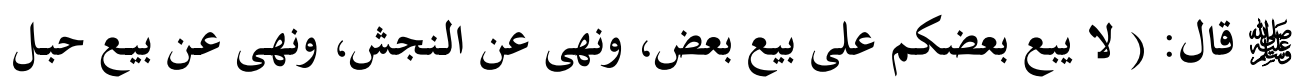

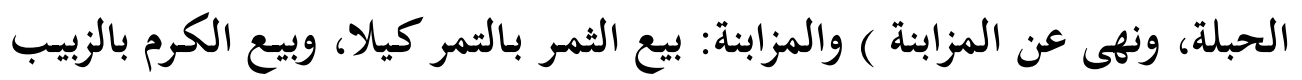
كيالا.

هذا حديث صحيح؛ أخرجه البخاري في صحيحه عن عبد الله بن يوسف، ما

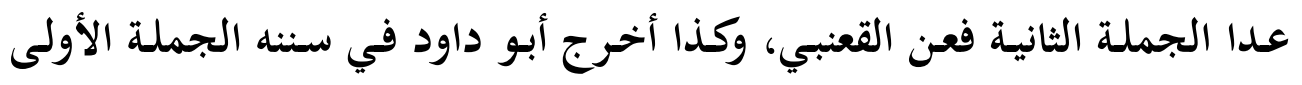

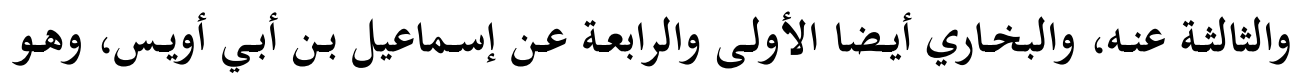

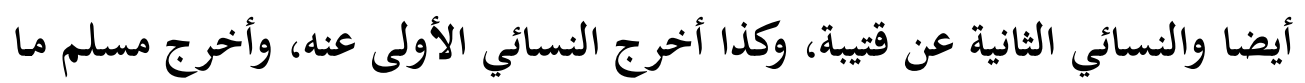

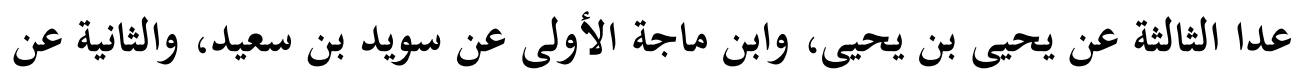

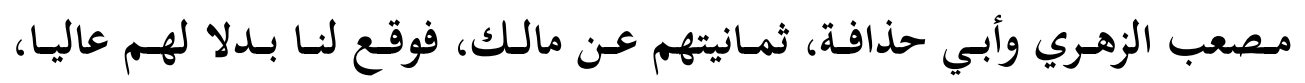

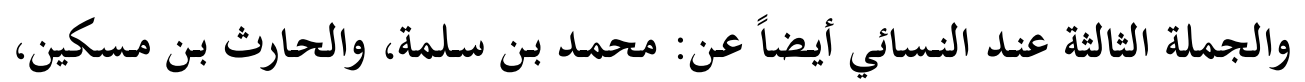

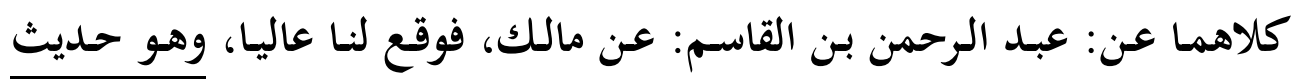

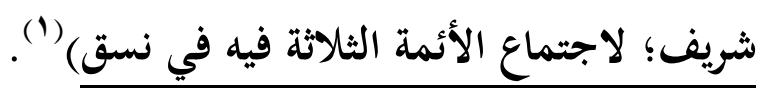

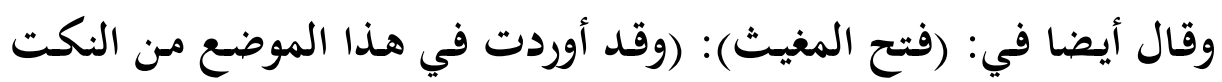

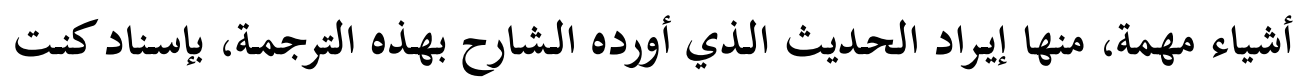

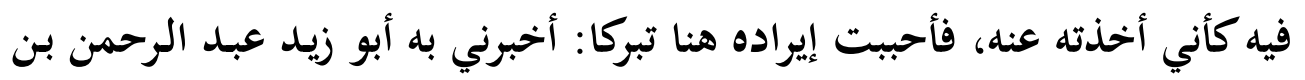

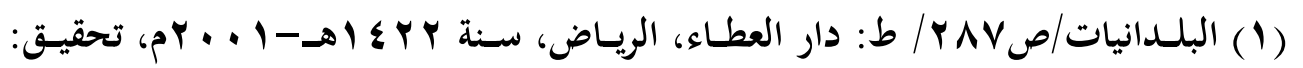
حسام محمد القطان. 
عمر المقدسي الحنبلي في كتابه، والعز أبو محمد عبد الرحيم بن محمد المصري الحنفي سماعا.

قال الأول: أخبرنا أبو عبد الله محمد بن أبي الفداء ابن الخباز أذنا: أخبرنا أبو القائم المسلم بن محمد بن المسلم بن مكي القيسي الدمشقي.

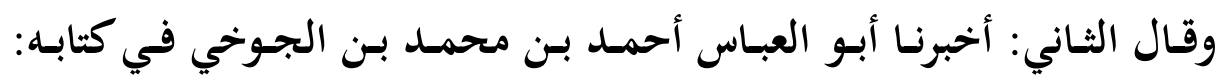
أخبرتنا أم أحمد زينب ابنه مكي بن علي بن كامل الحرانيه.

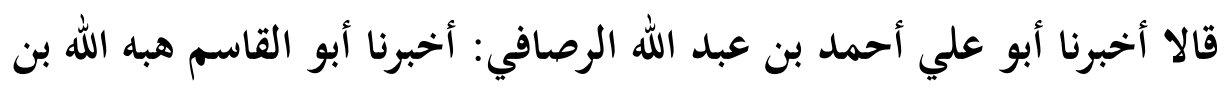

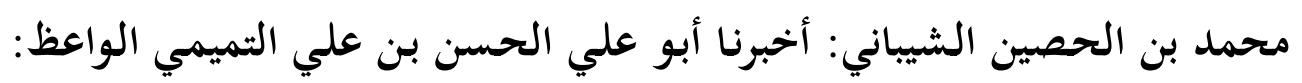

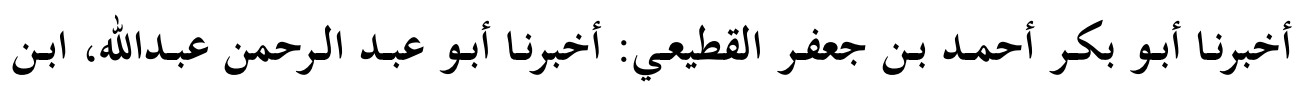

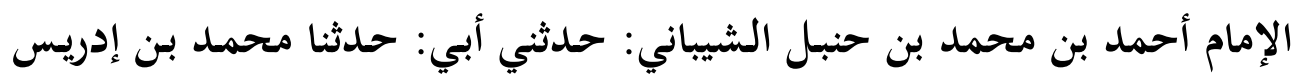

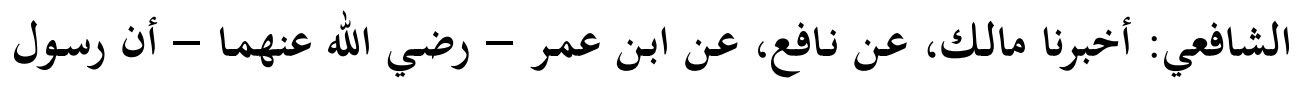

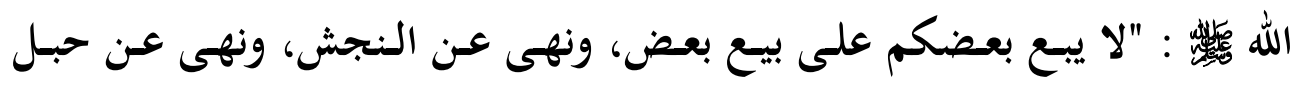
الحبلى، ونهى عن المزابنة".

والمزابنه بيع التمر بالتمر كيلا، وبيع الكرم بالزبيب كيلا، وهو مما اتفقا عليه مـن حسديث مالكك، إلالجملـة الثالثـة فهي مـن أفراد البخـاري، فوقـع لنـا بـدلا (1) لهما) 
وقد أسـنده الحـافظ السيوطي -رحمـه الله تعالى- في: ( تـدريب الراوي)،

قال: (أخبرني شيخنا الإمام: تقي الدين الشمني -رحمه الله- بقراءتي عليه، أنا:

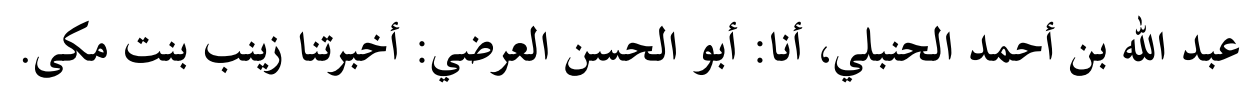

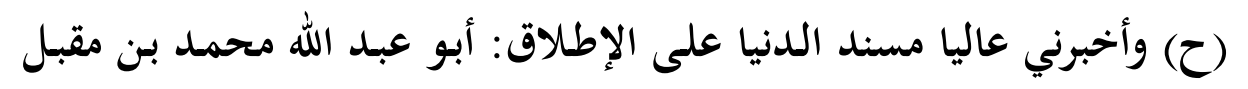

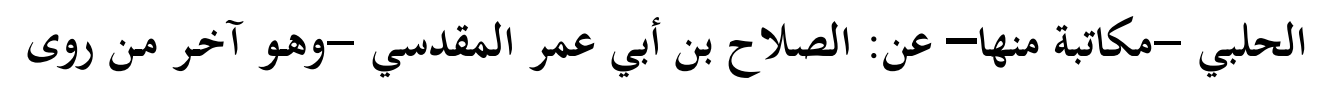

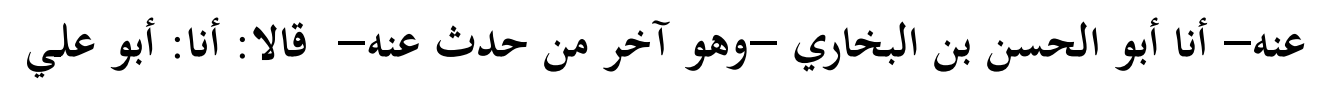

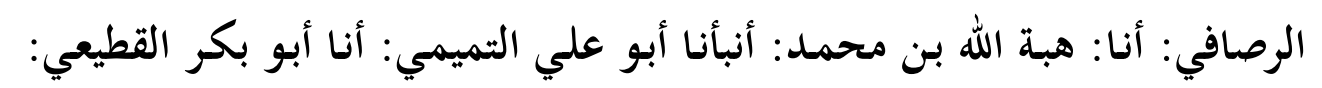

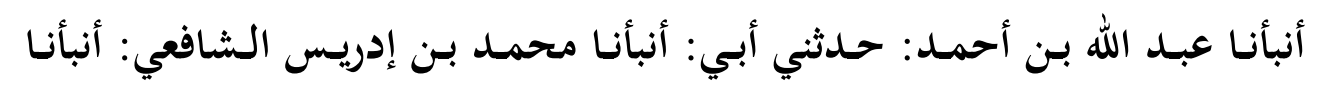

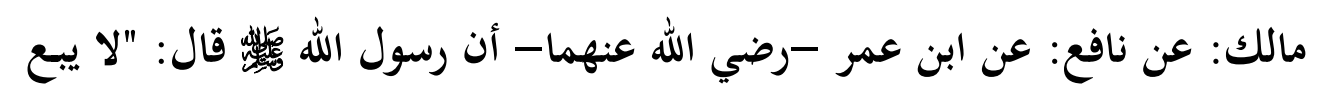

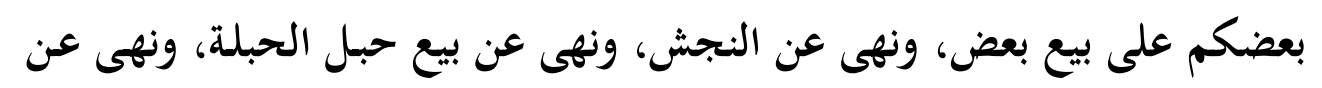
المزابنة"، والمزابنة: بيع التمر بالتمر كيلا، وبيع الكرم بالزبيب كيلا.

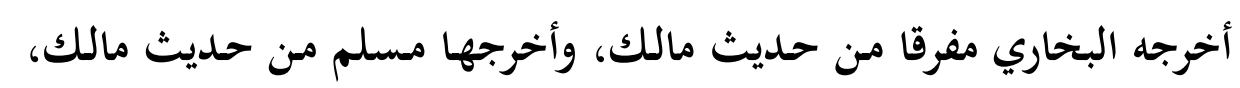
إلا النهي عن حبل الحبلة، فأخرجه من وجه آخر) (1).

وأسنده ابن العماد الحنبلي في: (شذرات الذهب) مفتخرا به، فقال: (منها

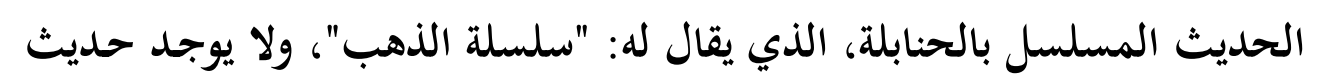

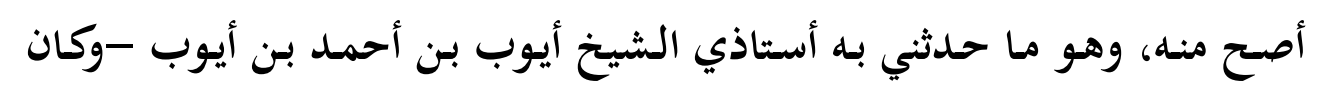

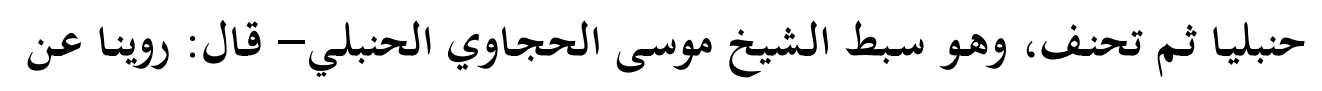

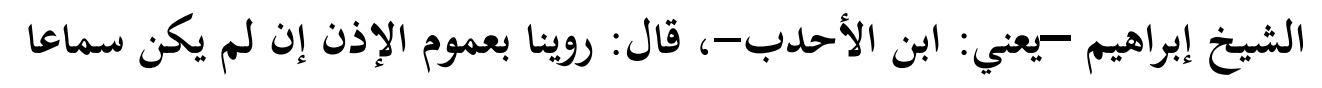

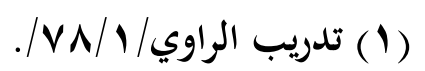




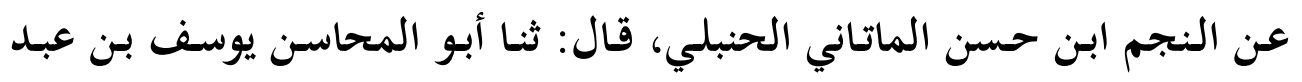
الهادي الحنبلي: ثنا جدي أحمد بن عبد الهن الهادي الهنبي الحنبلي.

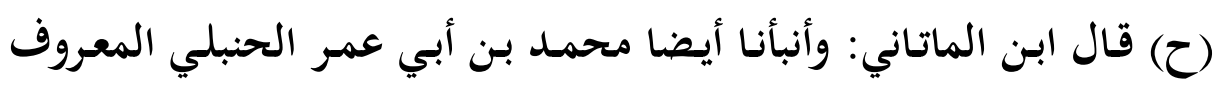

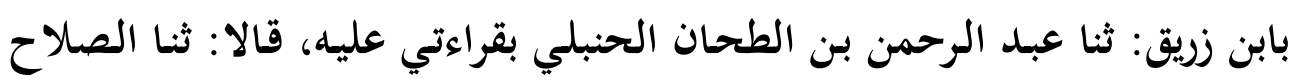

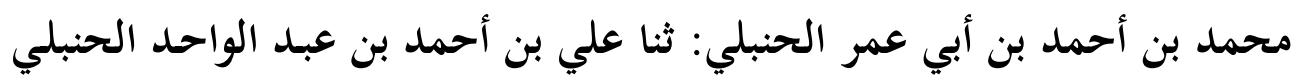

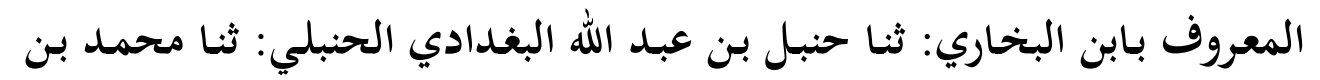

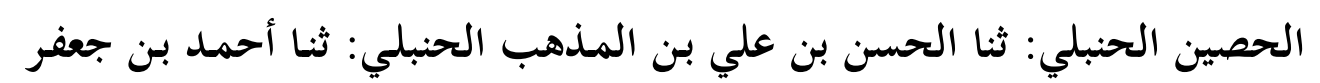

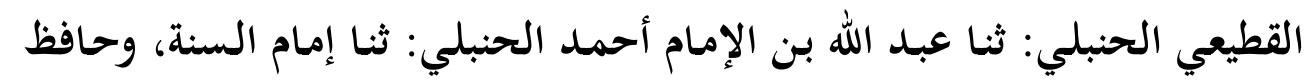

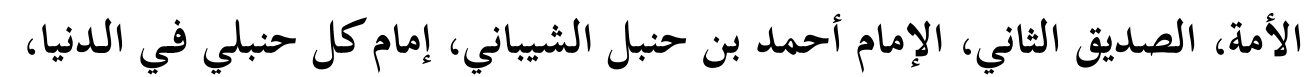

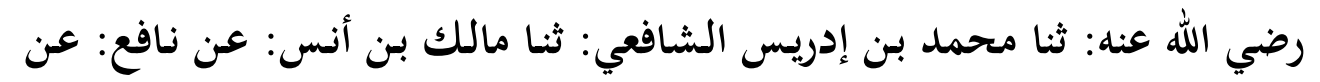

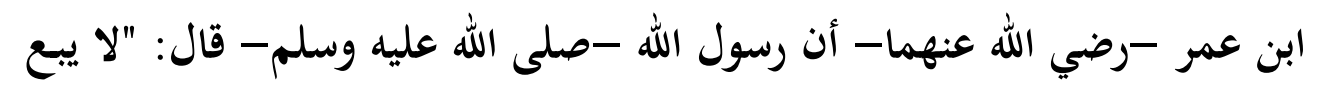
بعضكم على بيع بعض ونهى عن النجش ونهى عن بيع حبل الحبلة ونهى عن

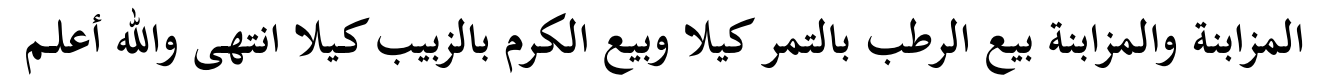
وله الحمد والمنة) (1).

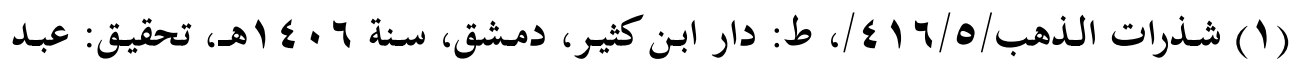

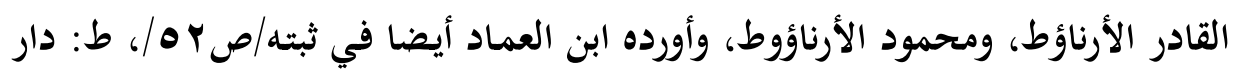

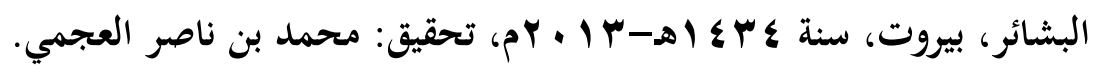




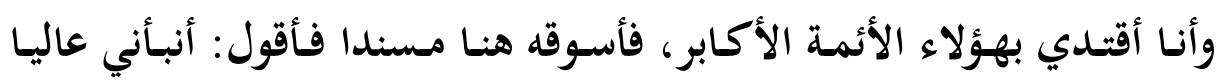

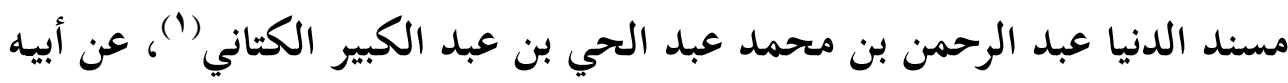

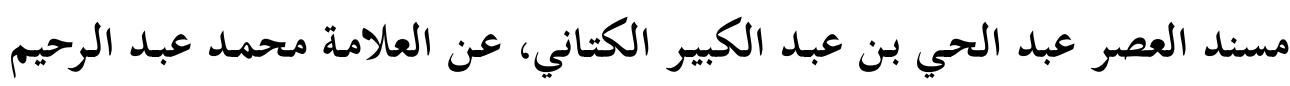

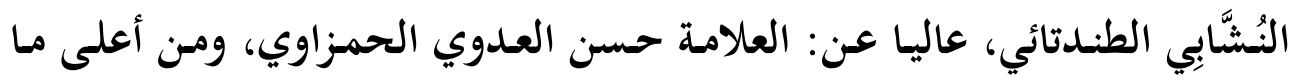

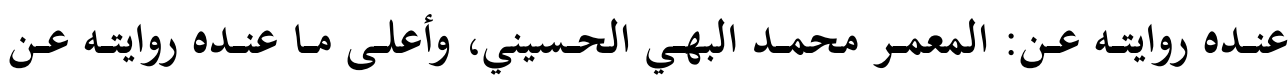

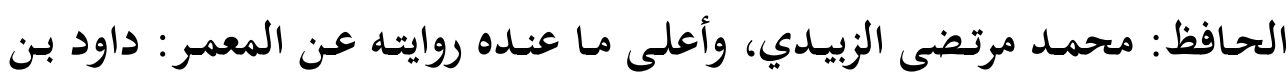
سليمان الخربتاوي، وأعلى ما عنده روايته عن المعمر الشمس الفيومي، وأعلى ما

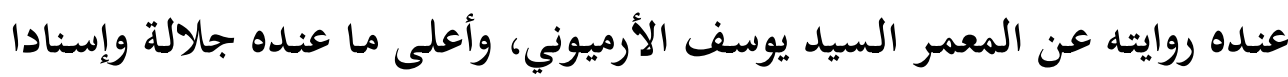

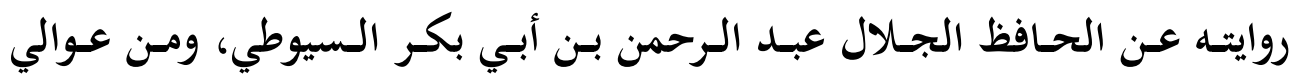

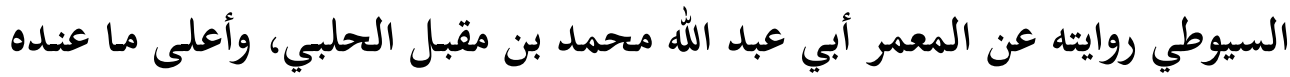
روايته عن الصلاح بن أبي عمر المقدسي، وأعلى ما عنده روايته عن الفخر بن

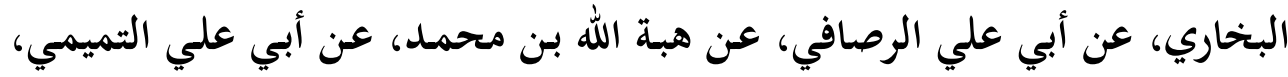

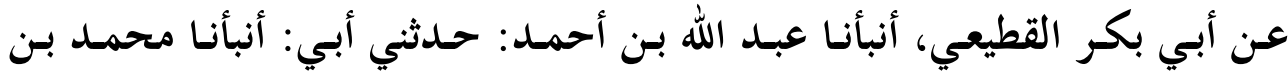

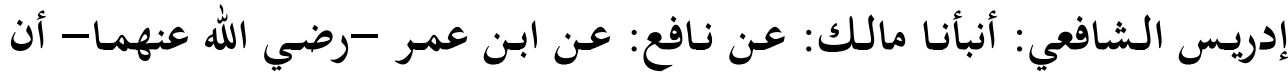
رسول الله

(1) وانظر في أسـانيد شيخنا السيد عبد الرحمن بن محمد عبد الحي الكتاني وترجمته

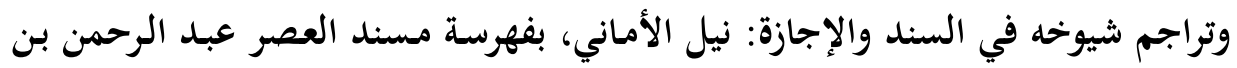

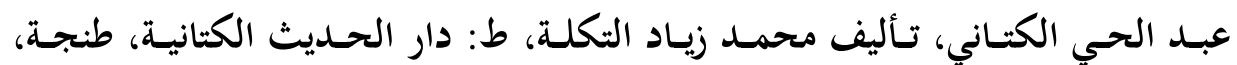

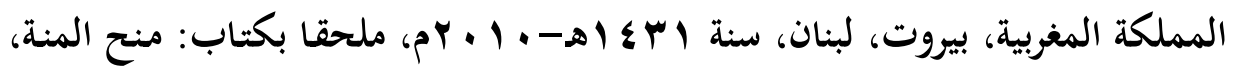

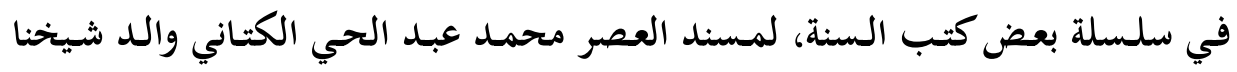

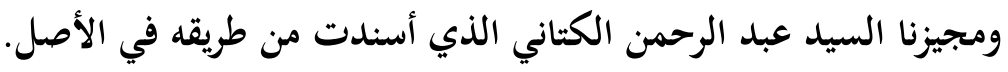


بيع حبل الحبلة، ونهى عن المزابنة)، والمزابنة: بيع التمر بالثمر كيلا، وبيع الكرم بالزبيب كيلا.

قال الحافظ التاج السبكي -رحمه الله تعالى - في: (طبقات الشافعية): (هذا

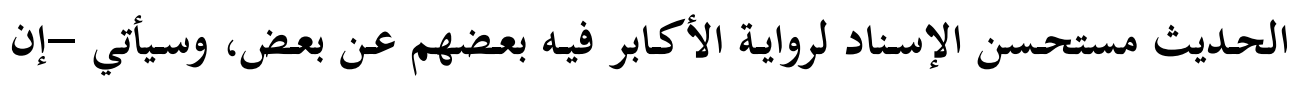
شاء الله تعالى - مثله في ترجمة المزني.

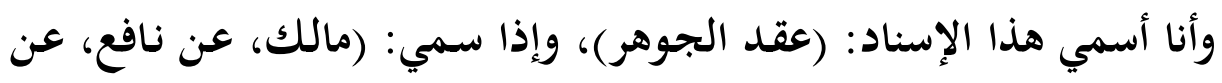

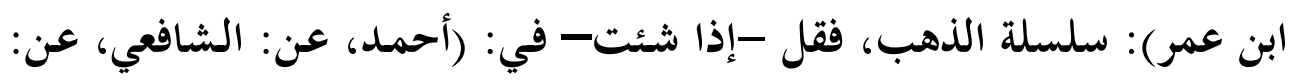
مالك، عن: نافع، عن: ابن عمر، و :المزني، عن: الشافعي هكذا، والبويطي عن:

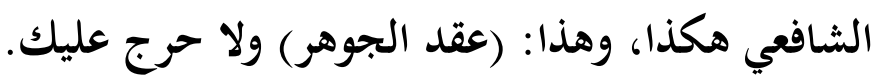

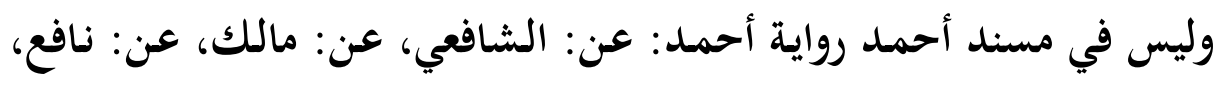

$$
\text { عن: ابن عمر غير هذا الحديث) (1). }
$$

وقد تفرع على ذلك مبحث آخر، وهو البحث في أصح الأحاديث، بعد أن سبق البحـث في أصـح الأسـانيد، فقـال الحـافظ أبـو سعيد العلائي في: (بغيـة الملتمس): (هذا حديث عزيز الوجود، ليس في الدنيا أصح منه، فقد تقدم قول

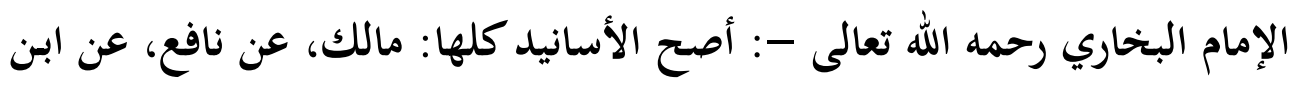

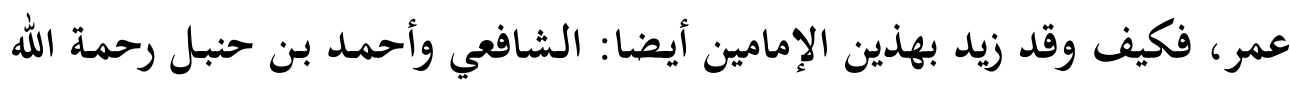
تعالى عليهم) (r)

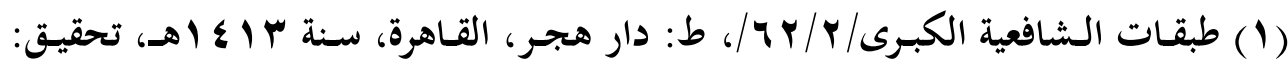
الدكتور محمود الطناحي، والدكتور عبد الفتاح الحلو.

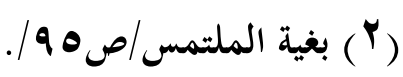




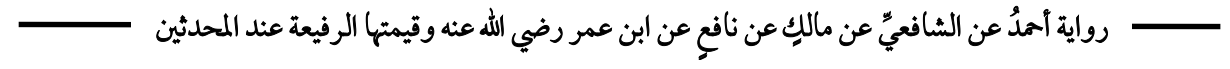

قـال الحـافظ السيوطي -رحمـه الله تعـالى- في: (تسدريب الراوي): (قـال

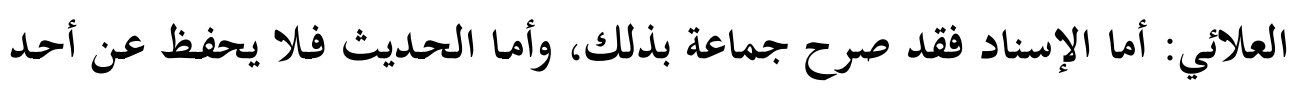

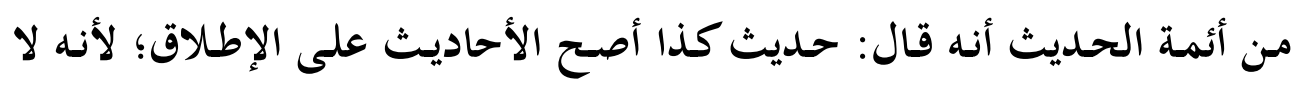

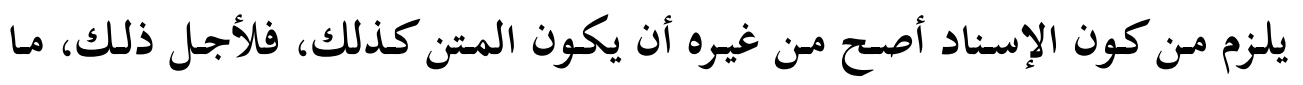
خاض الأئمة إلا في الحكم على الإسناد. وكأن المصنف حذفه لذلك، لكن قال شيخ الإسلام: سيأتي أن من لازم ما إلادياد

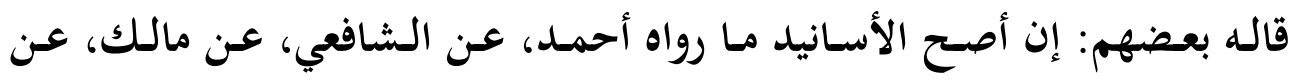

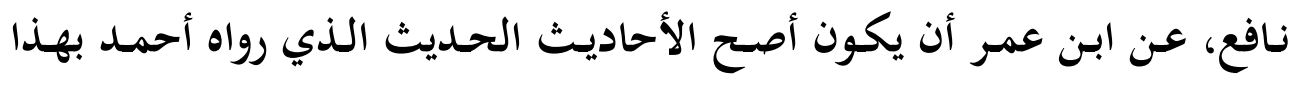

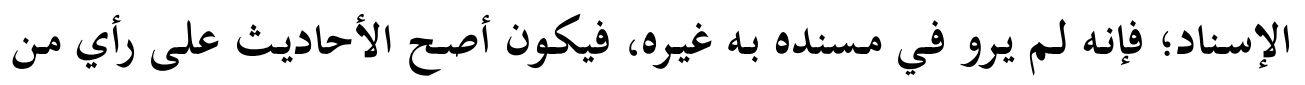

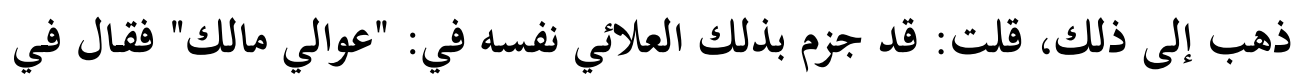
الحديث المذكور: إنه أصح حديث في الدنيا) (1). 


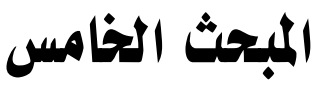

في خلو موطأ مالك من هذا

الحديث، وانقطاع سند الموطأ برواية الشافعي رغم أنه أقرأه للإمام

$$
\text { أحمد }
$$

وليس الحديث المذكور في الموطأ، بل ما اتفقت فيه تلك اللطيفة الإسنادية

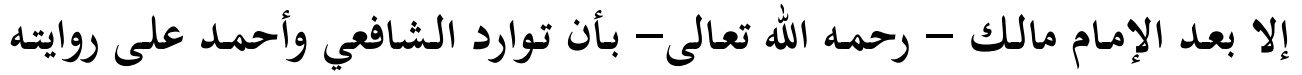
من طريقه هو كما هو بين، بل وكم لمالك من الحديث الكثير، مما لم يودعه هو في الموطأ، فرواه عنه أكابر أصحابه، وخرجه من طريقهم الحفاظ في تصانيفهم، قال الإمام البيهقي -رحمه الله تعالى- في: (السنن الكبرى): (ولمالك بن أنس

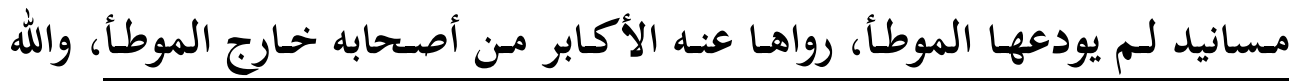

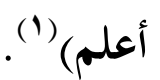

قـال المـلا علي القـاري -رحمـه الله تعـالى- في: (مرقـاة المفـاتيح): (قـال

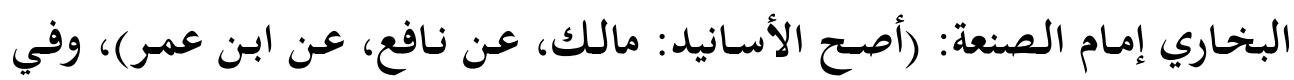

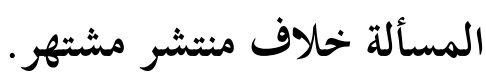

وعلى هذا المذهب قالوا: أصح الأسانيد عن مالك: الشافعي؛ إذ هو أجل مال

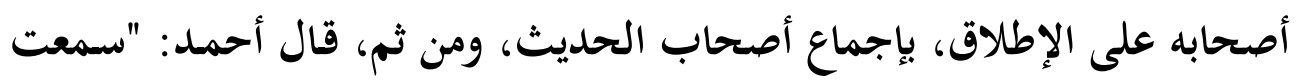

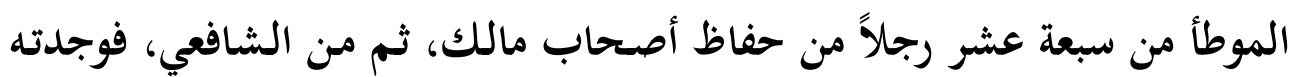

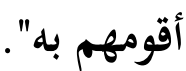

$$
\text { (1) السنن الكبرى/0/ ؟ ؟ ب/. }
$$


وأصحها عن الشافعي: أحمد، ولاجتماع الأئمة الثلاثة في هذا السند قيل

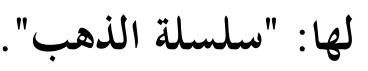
قيل: ولا ينافي ذلك إكثار أحمد في مسنده إخراج حديث مالك من غير

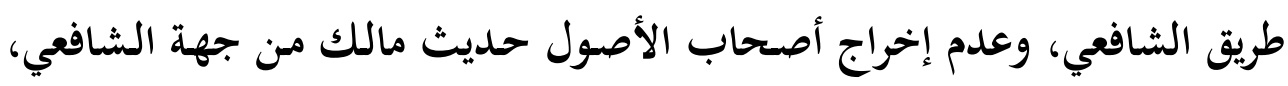

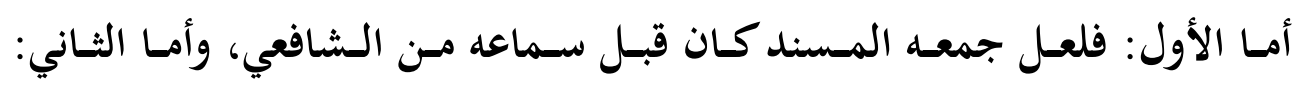
فلطلبهم العلو المقدم عند المحدثين على ما عداه من الأغراض) (1).

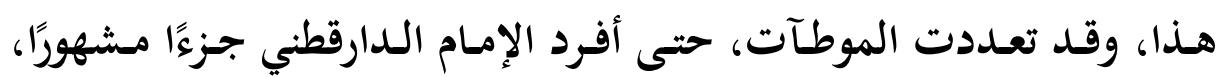
اسمه: (اختلاف الموطآت)، وقد وقف عليه الحافظُ ابنُ حجر، وهو ينقل منه في

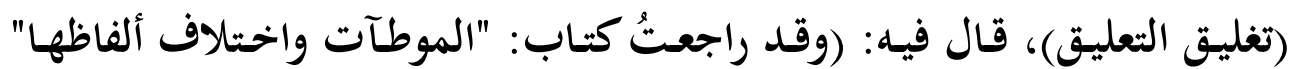
للدارقطني، فلم أجد طريق إسماعيل بن أبي أويس فيه فينظر) (َّ). قال العلامـة الشيخ طاهر الجزائري في: (توجيه النظر): (ولم يزل المئ الموطأ

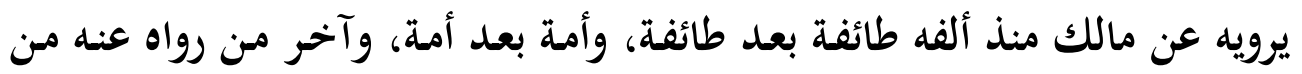
الثقات أبو المصعب الزهري، لصغر سنه، وعاش بعد موت مالك ثلاثًا وستين

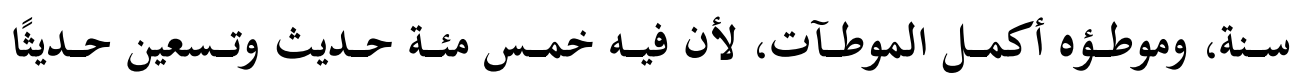
بالمكرر، أما بإسقاط النكرار فخمس مئة حديث وتسعة وخمسون حديثا) (َّ).

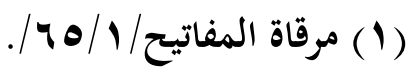

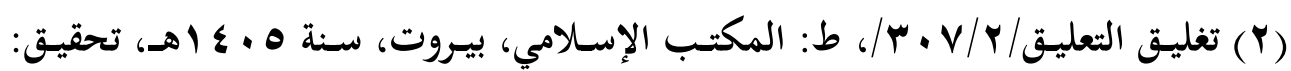

$$
\text { سعيد عبد الرحمن القزقي. }
$$

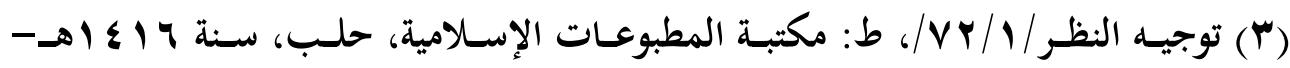
ه9 99 1م، تحقيق العلامة المحدث الثيخ عبد الفتاح أبو غدة. 
ولشيخ الإسلام الحافظ أبي الفضل ابن حجر العسقلاني أيضا جزءٌ اسمه:

$$
\text { (زيادات بعض الموطآت على بعض). }
$$

والحاصل أن منها روايةً الشافعيّ عن مالكٍٍ، إلا أنه لم يصل إلينا موطأُ مالكٍ

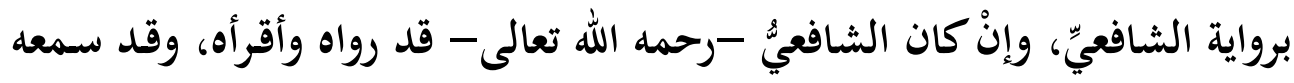

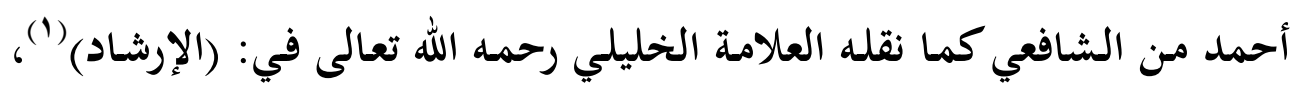

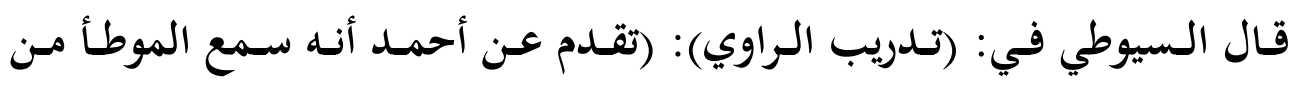

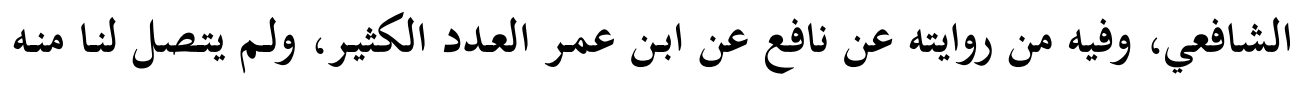

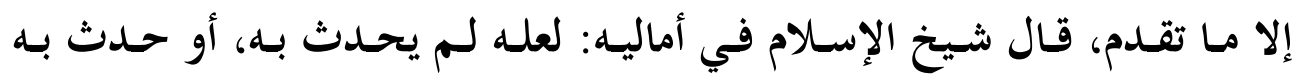

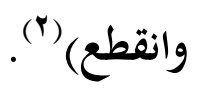

والموجـودُ عنــنا مـن روايـة أحمـد عـن الـشافعي ليس بـالكثير، وقـد أفرده

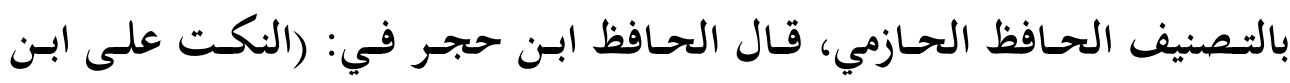
الصلاح): (وقد جمع الحافظ أبو بكر الحازمي في ذلك جزءا سماه: "سلسلة

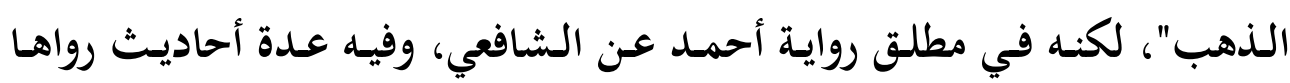

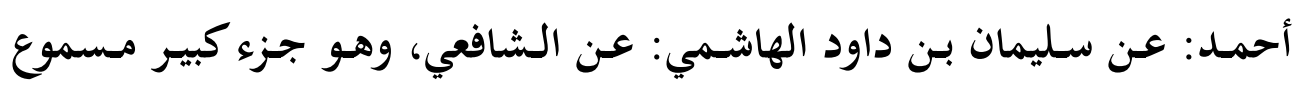
لنا (")

وقال أيضا في: (المعجم المفهرس): (كتاب: "سلسلة الذهب" للحازمي،

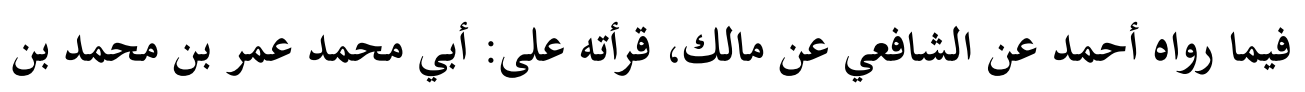

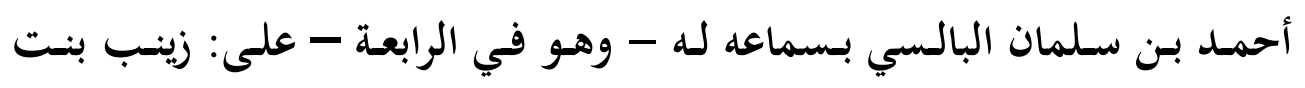

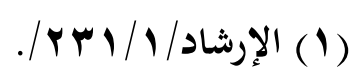

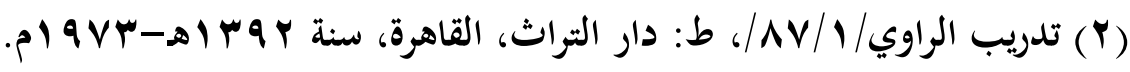

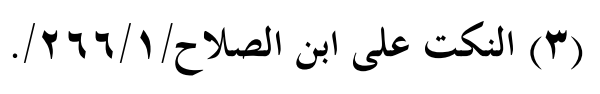




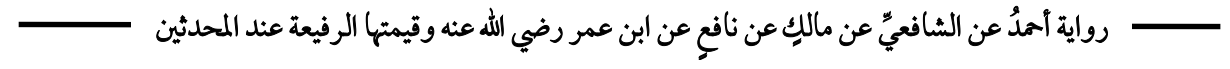

الكمال، وإجـازة منها له، عن عبد الخحالق بـن الأنجب المـارديني، أنبأنا مؤلفه.

الحافظ: أبو بكر محمد بن موسى الحازمي، قراءة عليه وأنا أسمع، فذكره) (1).

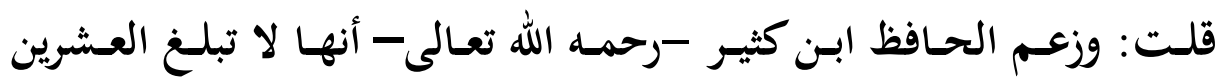

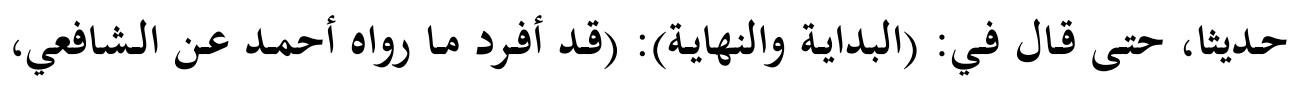

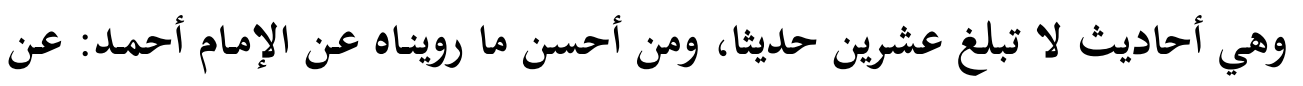

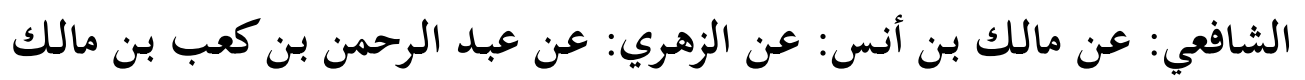

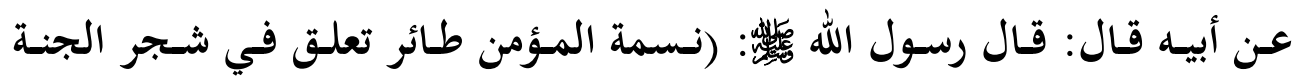

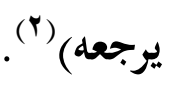
فإن أضفت إلى السلسلة مالكا -وإن لم يقيد بروايتة عن نافع - ازداد قلة، إنة حتى إنها بعد استقصاء وتفتيش لا تبلغ العشرة الأحاديث. قال الحافظ ابن حجر -رحمه الله تعالى- في: (النكت على ابن الصلاح): (وجمعتها مع ما يشبهها من رواية أحمد عن الشافعي عن مالك، ومع عدم التقييد بنافع في جزء مفرد، فما بلغت عشرة، والله الموفق) (بات.

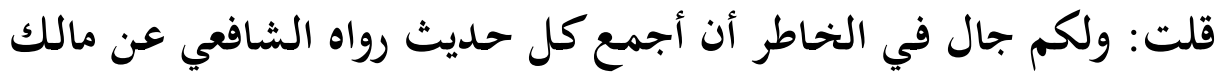
في جزء، وهو حديث كثير، طالما وقعت عيني في كتب الحديث عليه، لا سيما في كتب البيهقي، وشأنه في هذا الباب معلوم.

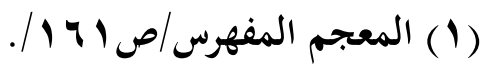

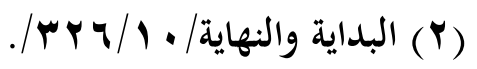

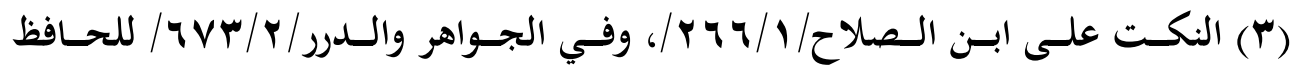
السخاوي ذكر لجزء الحافظ ابن حجر في (أحاديث أحمد عن الشافعي عن مالك)، 
بل كم نبه البيهقي -رحمه الله تعالى - على أوهام وقعت في نقل الرواة عن

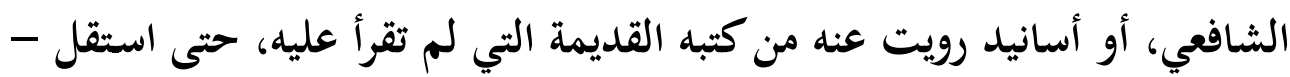

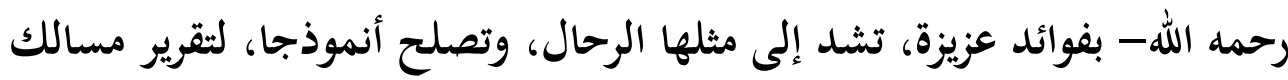
النقد والتعليل عند هذه الطبقة من الحفاظ. قال في: (معرفة السنن والآثار): (قال أحمد -قلت: يعني نفسه-: فظن أبو

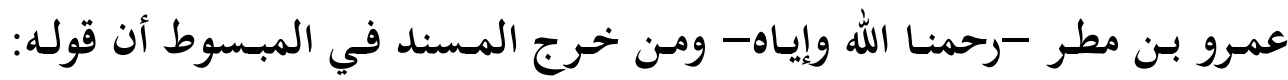
(وجاء العجلاني) من قول هشام بن عروة، فخرجه في المسند مركباً على إسناد

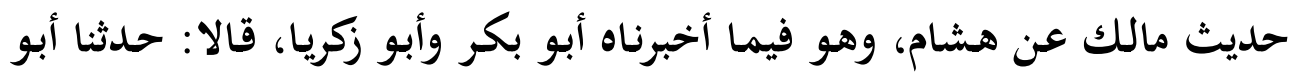

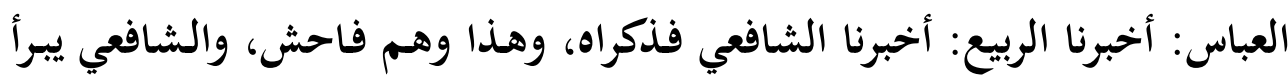

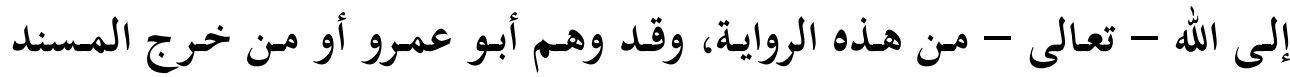
وهكذا، في غير حديث مما خرجه في المسند، وقد ذكرته في هذا الكتاب وبينته وبالله التوفيق.

قال أحمد: وهذا الحديث فيما قرأته على أبي سعيد بن أبي عمرو في كتاب:

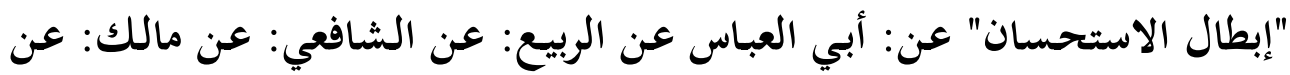

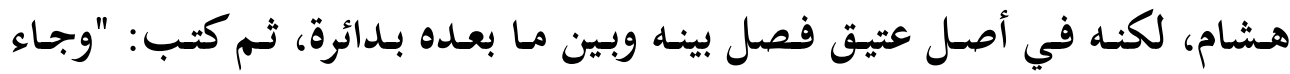
العجلاني"، وتفكر في قوله: "عن هشام بن عروة"، "وجاء العجلاني" علم أنه

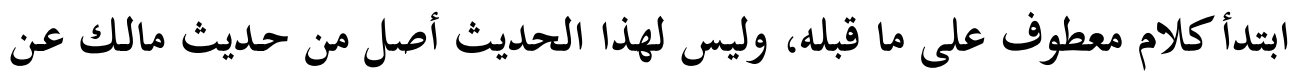
هشام عن أبيه عن زينب عن أم سلمة، ثم بحديث العجلاني، وأنا مستغن عن هذا 
الشرح، لكن لبعد أفهام أكثر الناس عن هذا الشأن هو، ولا أحتاج في مثل هذا

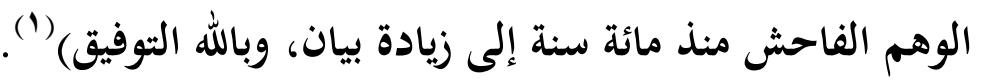

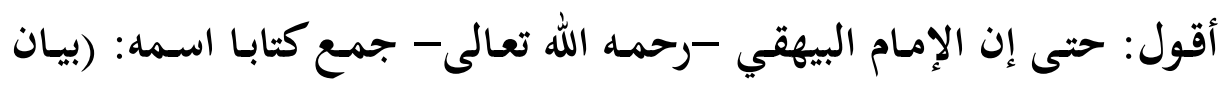

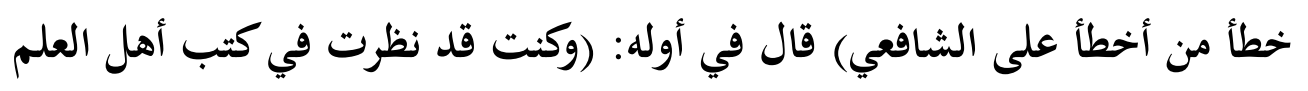

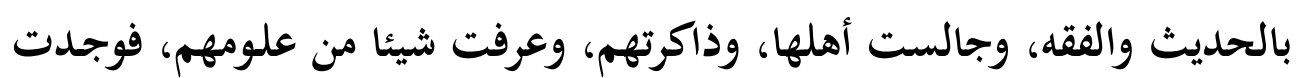

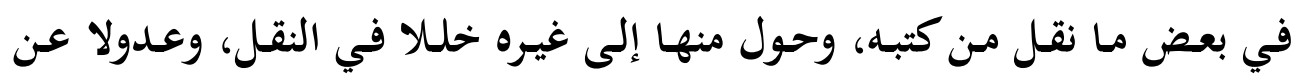

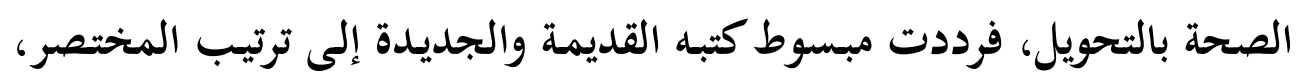

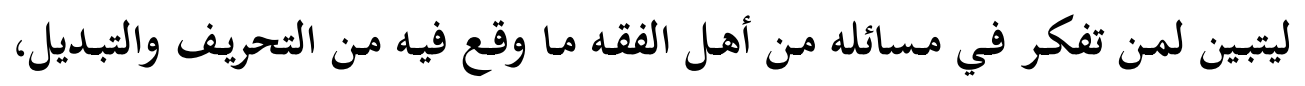
ويظهر لمن نظر في أخباره من أهل العلم بالحديث ما وقع فيه الخلل، بالتقصير

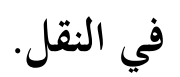

ثم حين صـنفت كتاب: "معرفة السنن والآثار عن الشافعي" بينت فيـه مـا عثرت عليه من خطأ من أخطأ عليه في الأخبار، فسألني بعض إخواني من أهل

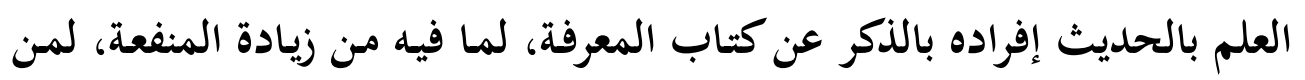
تتبع المسند أو المختصر في الوقوف عليه، ولم يهتد في كتاب المعرفة إليه، فأجبته إلى ملتمسه، مستعينا بالله عز وجل في إتمامه، وانتفاع الناظرين فيه بـه، متوكلا عليه فيه وفي جميع أمورنا، وهو حسبنا ونعم الوكيل ونعم المعين) (؟ّ).

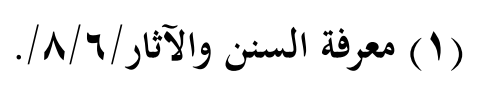

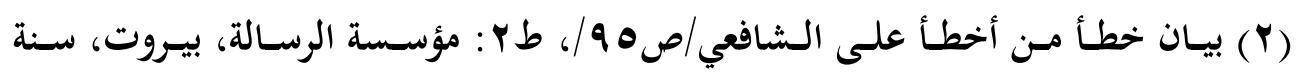

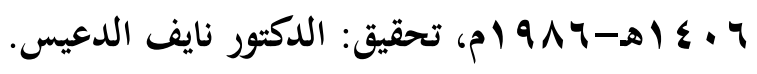




\section{المجثث السادس}

\section{في أن هذا السند لا ينظر فيه جرحا ولا}

تعديلا لتسلسله بالأئمة الحفاظ واستفاضة إمامة رجاله

ومثل هذا الإسـاد لا ينظر في رجاله جرحا وتعديلا، إذ رجاله أئمة الدين،

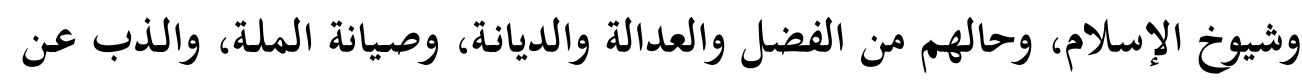

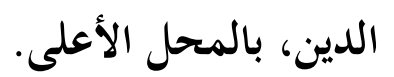

قال الحافظ أبو عمرو ابن الصلاح - رحمد الله تعالى - في: (المقدمة): (عدالة الراوي تارة تثبت بتنصيص معدلين علي عدالته، وتارة تثبت بالاستفاضة،

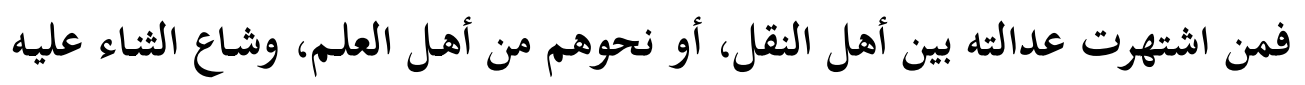
بالثقة والأمانة، استغني فيه بذلك عن بينة شاهدة بعدالته تنصيصا.

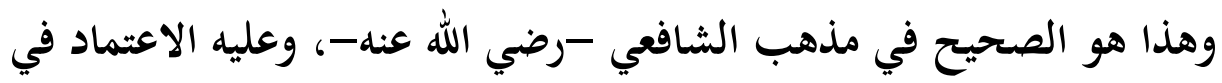

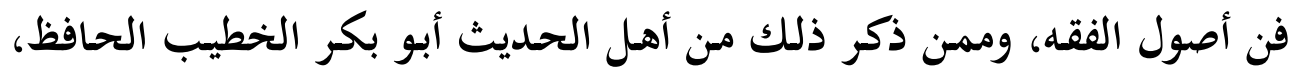

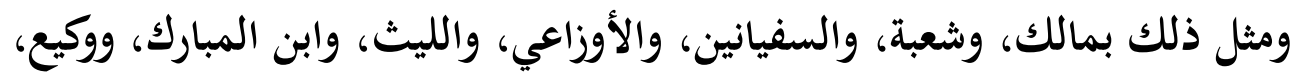
وأحمد بن حنبل، ويحيى بن معين، وعلي بن المديني، ومن جري مجراهم، في

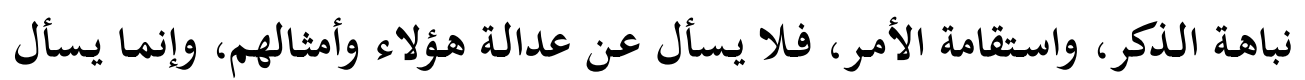

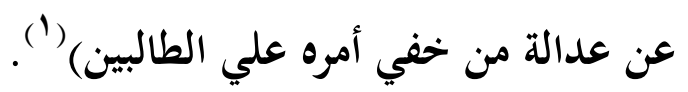
حتى صار هذا السند الجليل مثلا يضرب في تواتر العدالة، والاستغناء عن العن التفنيش عن حال رجاله، فقال حجة الإسلام الغزالي في: (المستصفى): (فينبغي

$$
\text { (') مقدمة ابن الصلاح/صع • 1/. }
$$




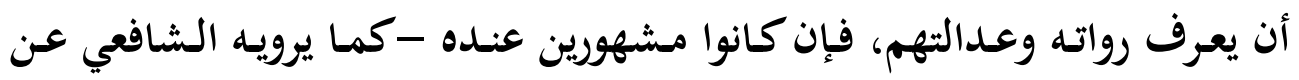

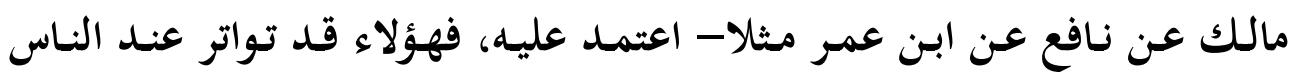

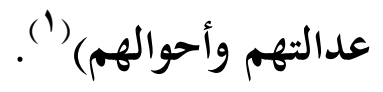

قال الحافظ الذهبي -رحمه الله تعالى- في: (تاريخ الإسلام) ترجمة حافظ

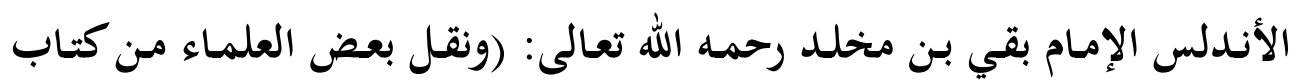

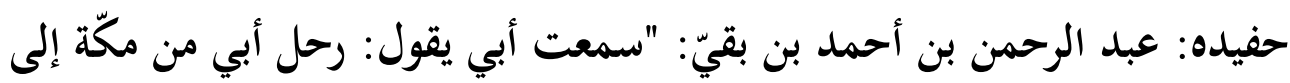

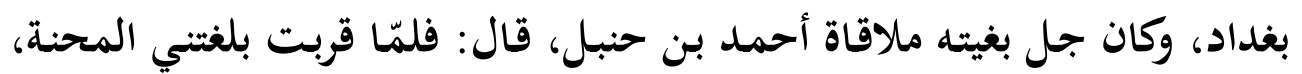

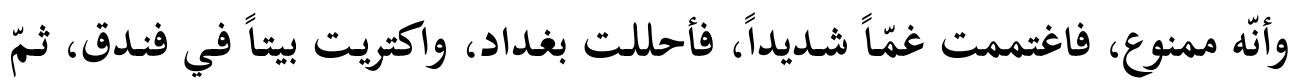
أتيت الجامع وأنا أريد أن أجلس إلى النّاس، فدفعت إلى حلقةٍ نبيلة، فِإذا برجلٍ

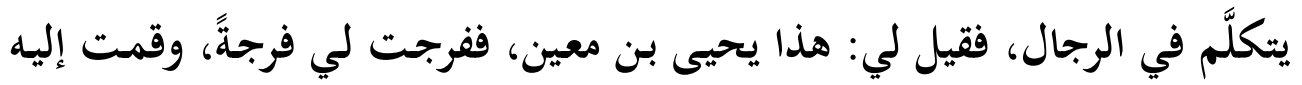

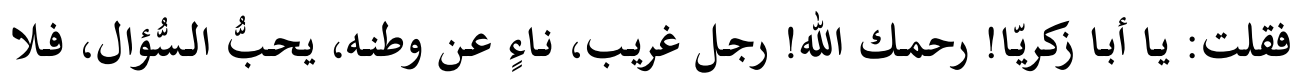

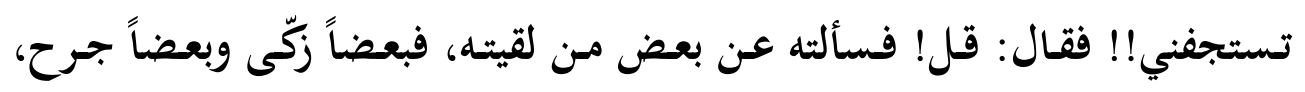

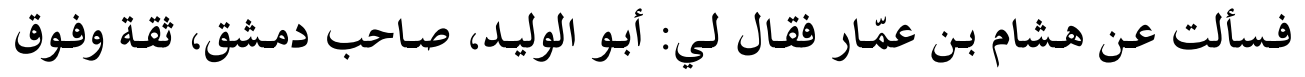

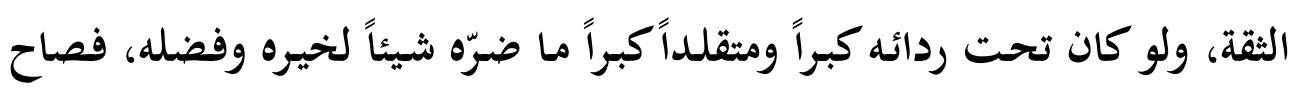

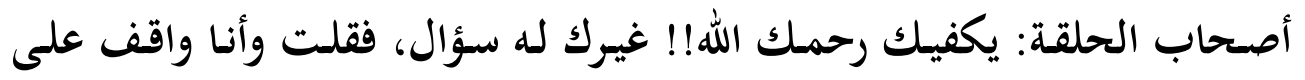
قدميّ: أكشفك عن رجلِ واحد، أحمد بن حنبل!! فنظر إليَّ كالمتعجّب وقال لي: ومثلنـا نحن نكشف عن أحمد بـن حنبل؟! ذاك إمام المسلمين، وخيرهم،

(1) المستصفى/\&/ / / /، تحقيق: الدكتور حمزة بن زهير حافظ. 
وفاضلهم)(")، قلت: فتعجب من وقوع السؤال عن حال الإمام أحمد، وهو من

وقال الحافظ الذهبي في (ميزان الاعتدال): (وكذا لا أذكر في كتابي من

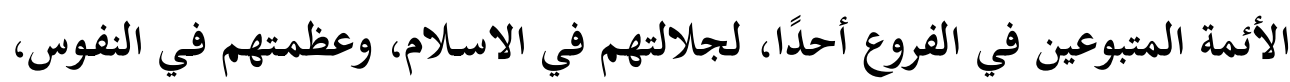

مثل أبي حنيفة والشافعي والبخاري) (؟).

قال الحافظ ابن حجر في: (نزهة النظر): (ومنها المسلسل بالأئمة الحفاظ

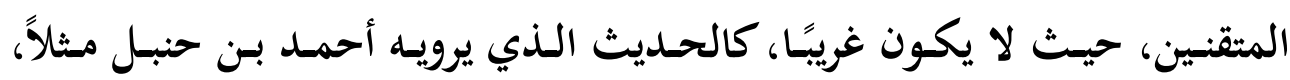

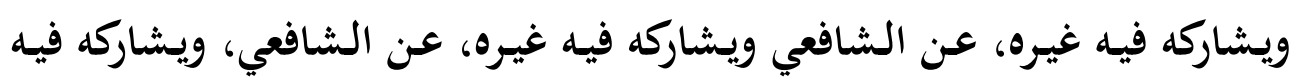

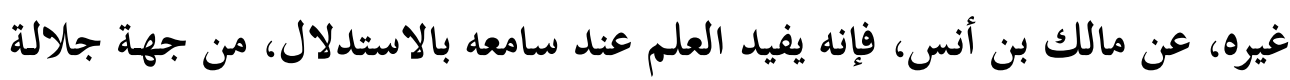

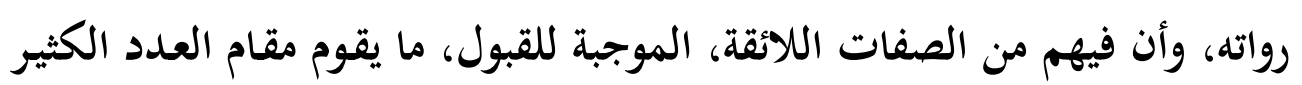
من غيرهم، ولا يتشكك من له أدنى ممارسة بالعلم وأخبار الناس، أن مالكا مثلاً

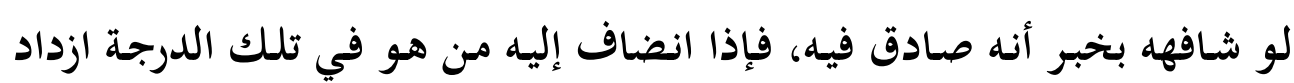

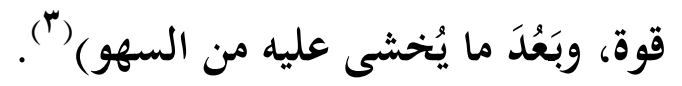

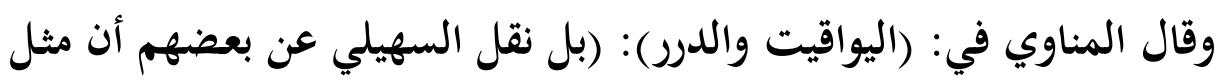

ذلك عن نافع موجب للعلم) (\&).

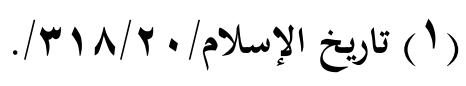

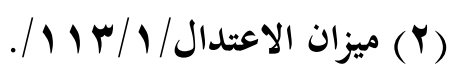

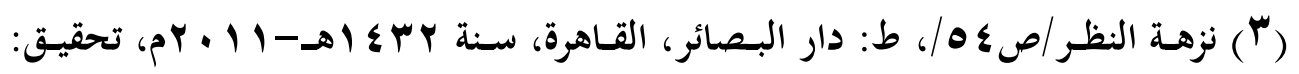

شيخنا العلامة المحدث نور الدين عتر.

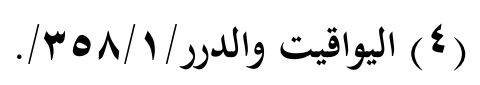


وقال الملا علي القاري في (شرح نخبة الفكر) ("فإن فيهم" أي ومن جهة

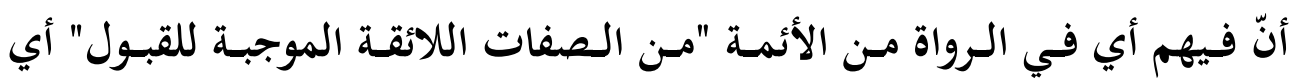

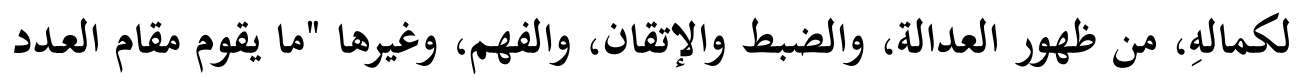
الكثير من غيرهم" ولذا يسمى مثل هذا الإمام: أمة، قال الله تعالى: "إن إبراهيم

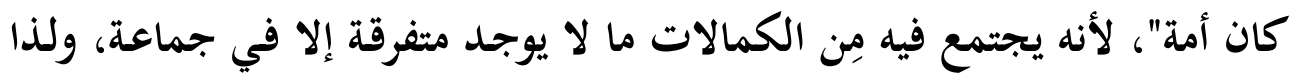

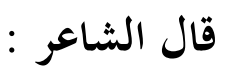

وليس مِن الله بمُسْتَنْكِكٍ

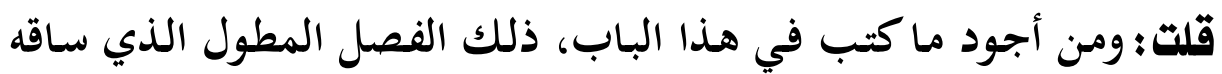

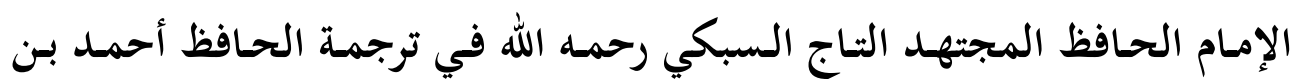

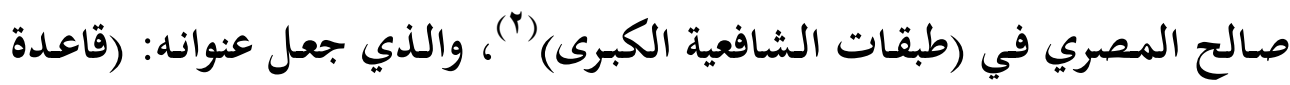

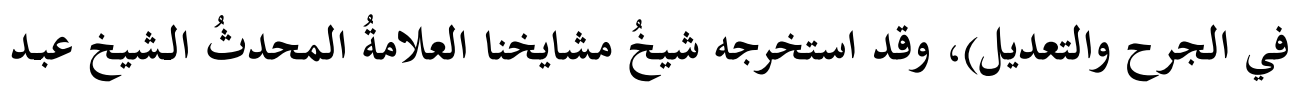
الفتاح أبو غدة، فطبعه في كتابٍ مستقلٍّ سماه: (قاعدة في الجرح والتعديل، وقاعدة في المؤرخين)، مع تعليقات له مهمة.

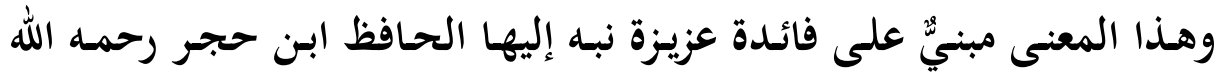
تعالى، فيما سبق من كلامه في (نزهة النظر)، حيث أفاد في غير موضع من تآليفه أن المعتبر في إفادة المتواتر العلم هو أن كثرة العدد والذوات ترفع ما يطرق خبر

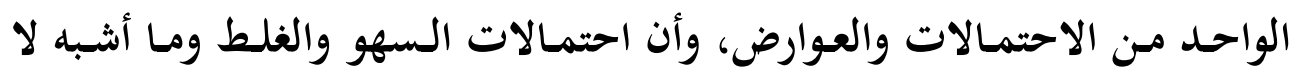
تزال تتناقص كلما كثر العدد، فبإذا مـا ظفرنا بشخص من الأئمة، استفاض عنده 


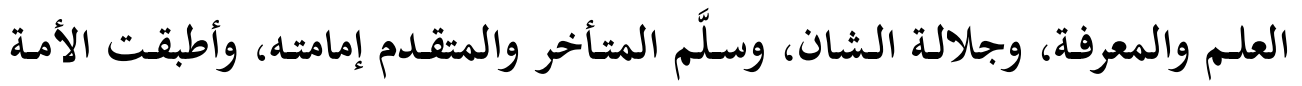

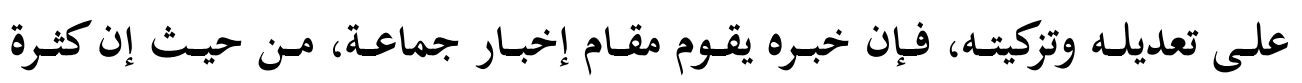
الصفات تنزل منزلة تعدد الذوات.

قال الحافظ ابن حجر -رحمه الله تعالى- في: (فتح الباري): (فإن العدد

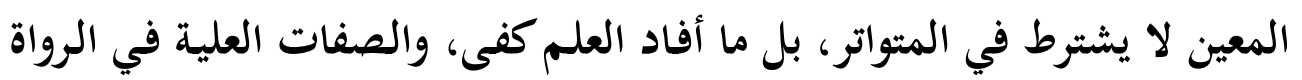
تقوم مقام العدد أو تزيد عليه، كما قررته في: "نكت علوم الحديث"، وفي: "شرح نخبة الفكر ") (1)

وقال أيضا في الفتح: (ففيه دليل على أن الصفات الموجبة للترجيح إذا

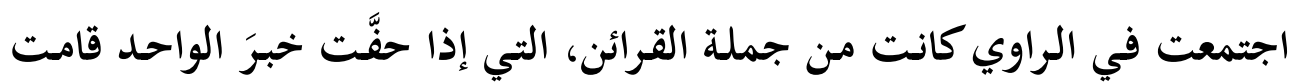
مقام الأشخاص المتعددة) (َ).

قال الحـافظ السخاوي في (فتح المغيـث): (إذ الصفات العليـة في الرواة تقوم مقام العدد، أو تزيد عليه هذا كله) (َ).

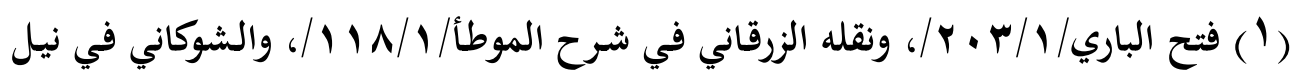

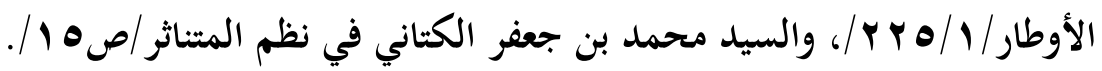

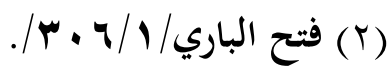

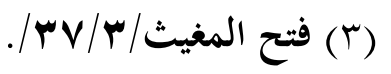


=

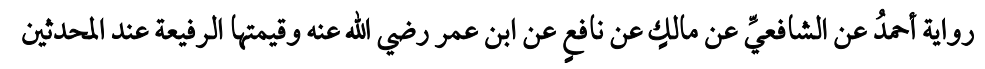

وهذا المعنى جليٌّ جليلٌ، قد نبه عليه جماعاتُ من أربابِ العلوم المختلفة،

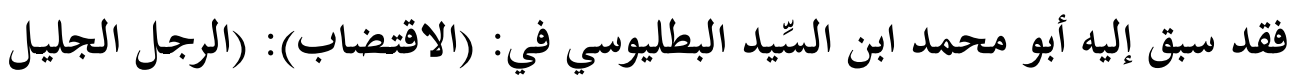
القدر ينوب وحده مناب جماعة، وينزل منزلة عدد كثير في فضله وعلمه) (1).

وهذا ختام هذا البحث، وصلى الله على خير خلقه سيدنا محمد رحمة الله للعالمين، وعلى آله وصحبه وسلم تسليما كثيرا.

(1) الاقتضاب، في شرح أدب الكتاب/ص • ؟/، ط: مطبعة دار الكتب والوثائق المصرية،

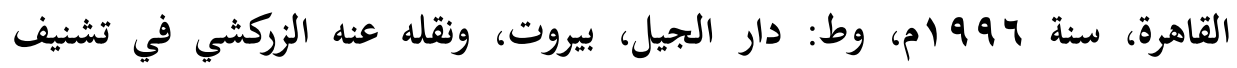

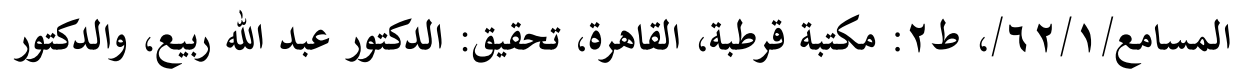

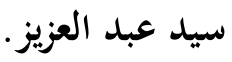




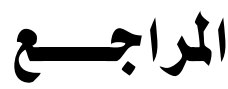

الإتقان، في علوم القرآن، للحافظ جلال الدين السيوطي، ط: دار الفكر،

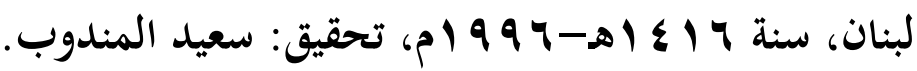

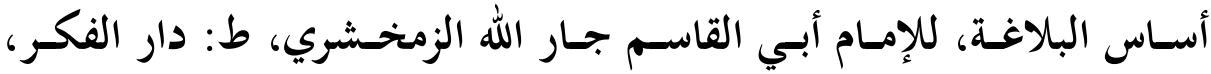

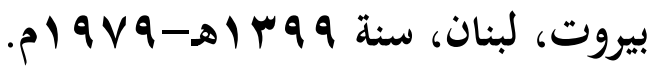
الإصابة، في تمييز الصحابة، للإمام الحافظ ابن حجر العسقلاني، ط: دار

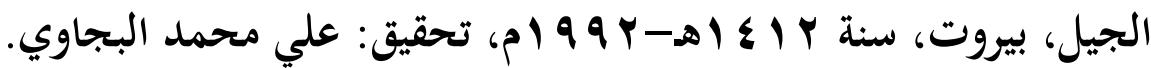
الاقتضاب، في شرح أدب الكتاب، للإمام أبي محمد ابن السيد البطليوسي، ط: مطبعة دار الكتب والوثائق المصرية، القاهرة، سنة جو 99 ام. م. البلـدانيات، للحسافظ محمـد بـن عبـد الرحمن السخاوي، ط: دار العطاء،

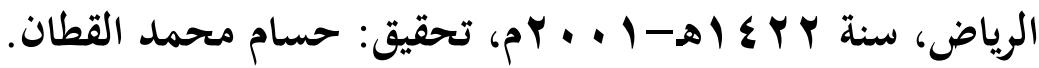
بيان خطأ من أخطأ على الشافعي، للإمام الحافظ أبي بكر أحمد بن الحسين

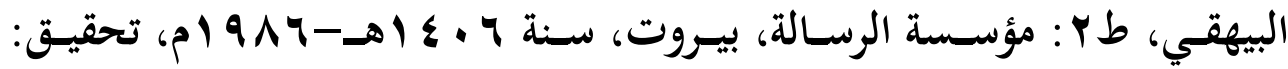
الدكتور نايف الدعيس.

تـاريخ الإسـلام، للحـافظ شـمس الـدين الـذهبي، ط: دار الكتـاب العربس،

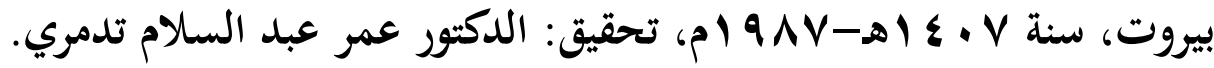

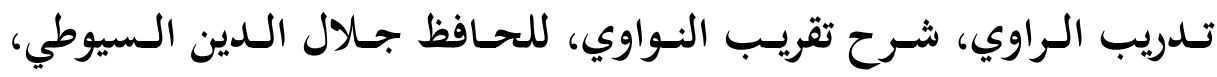
ط: دار التراث، القاهرة، تحقيق: الشيخ عبد الوهاب عبد اللطيف.

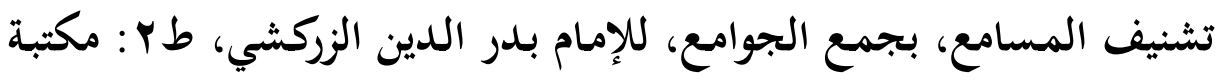
قرطبة، القاهرة، تحقيق: الدكتور عبد الله ربيع، والدكتور سيد عبد العزيز.

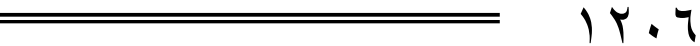


تغليق التعليق، لشيخ الإسلام الحافظ ابن حجر العسقلاني، ط: المكتب الإسلامي، بيروت، سنة ه ـ ـ اهـ، تحقيق: سعيد عبد الرحمن القزقي.

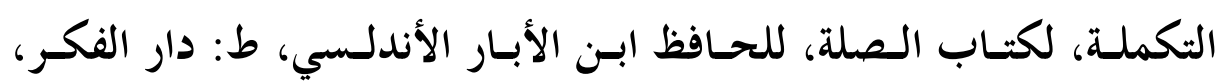
بيروت، سنة ه إ أهـ-ه 9 ( (م)، تحقيق: عبد السلام الهراس.

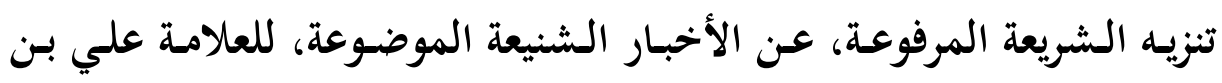

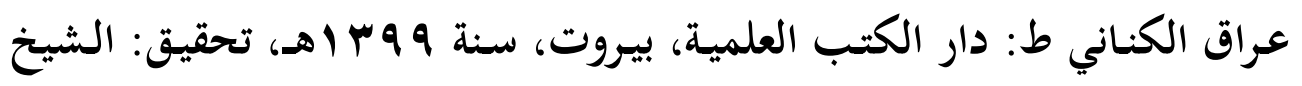

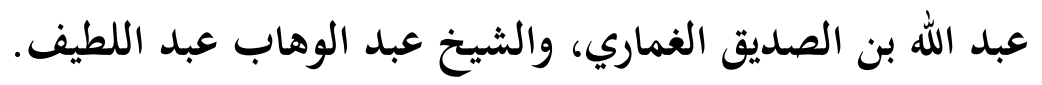

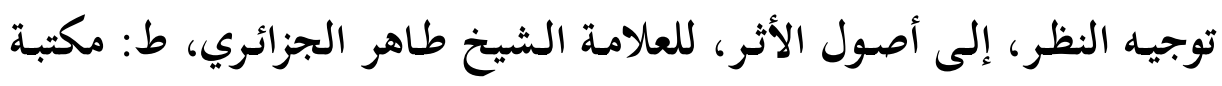

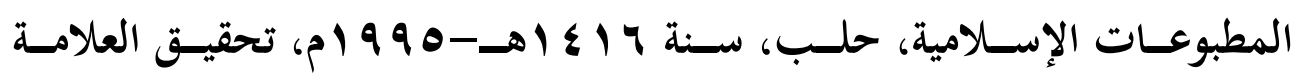
المحدث الشيخ عبد الفتاح أبو غدة.

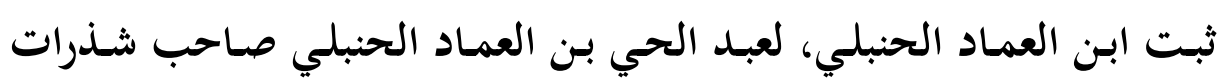

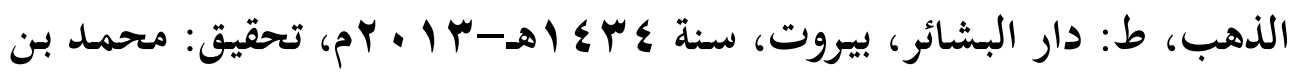
ناصر العجمي.

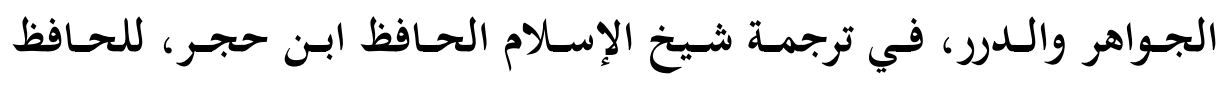

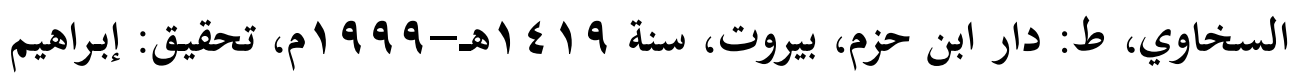
باجس عبد المجيد. ذم الكـلام وأهلـه، لأبسي إسـماعيل الأنسصاري الهـروي، ط: مكتبـة العلـوم

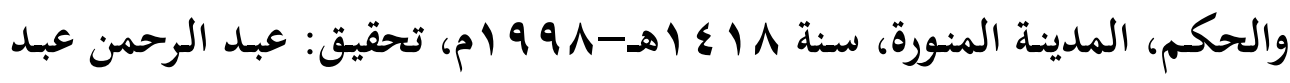

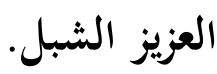
سير أعـلام النبلاء، للحافظ شـمس الدين الذهبي، طو: مؤسسة الرسالة، بيروت، سنة با اء أه، تحقيق: شعيب الأرناؤوط، ومحمد نعيم العرقسوسي. 
شـذرات الـذهب، في أخبـار مـن ذهـب، لعبـد الحي بـن أحمـد بـن العمـاد

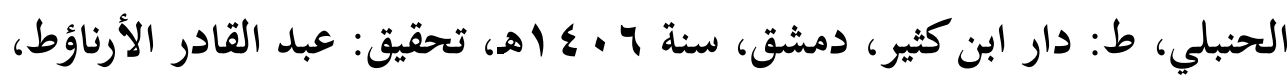
ومحمود الأرناؤوط شرح موطأ مالك، للعلامة محمد بن عبد الباقي بن يوسف الزرقاني، ط: دار

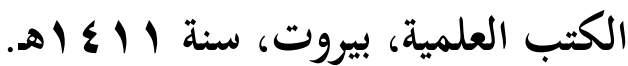
الضوء اللامع، في أعيان القرن التاسع، للحافظ شمس الدين السخاوي، ط: منشورات دار مكتبة الحياة، بيروت، (د ت).

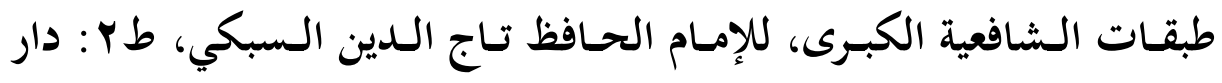
هجر، القاهرة، سنة با أ اهـ، تحقيق: الدكتور محمود محمد الطناحي، والدكتور عبد الفتاح محمد الحلو. عجائسب الآثـار، في التـراجم والأخبـار، لعبـد الرحمن بـن حسبن الجبرتسي

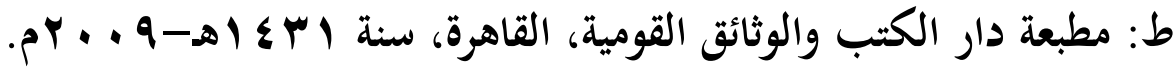
العجاب، في بيان الأسباب، للإمام الحافظ ابن حجر العسقلاني، ط: دار

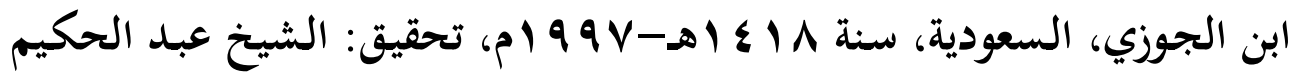
بن محمد الأنيس.

الفانيد، في حلاوة لأسانيد، للحافظ جلال الدين السيوطي، ط: دار البشائر الإسلامية، بيروت، سنة • بـ (هـ-999 (9)، تحقيق: رمزي سعد الدين دمثقية.

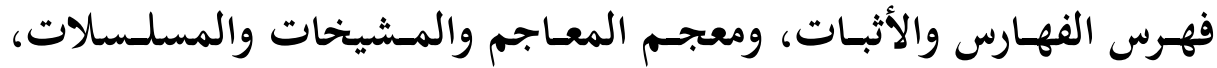
لمسند العصر محمد عبد الحي الكتاني، ط: دار الغرب الإسلامي، بيروت، سنة الته Y ب إهـ تحقيق: إحسان عباس. 
لسان الميزان، للإمـام الحـافظ شهاب الدين ابـ حجر العسقلاني، طس:

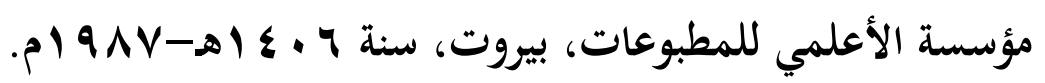

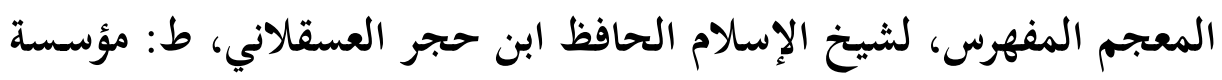

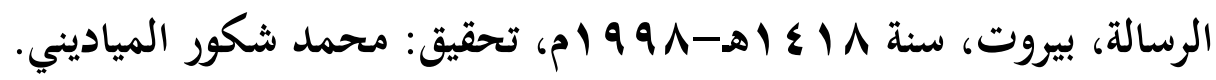

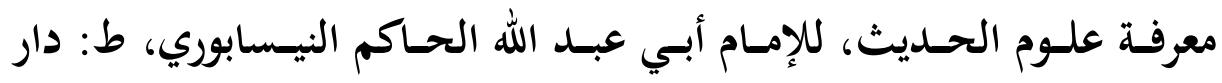
الكتب العلمية، بيروت، سنة MV M أه، تحقيق السيد معظم حسين.

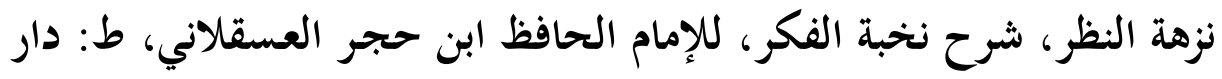

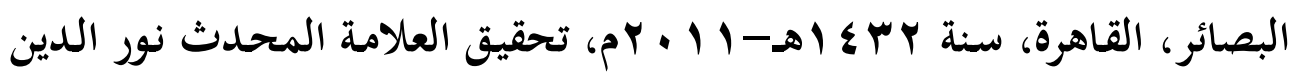
عتر. النكت على مقدمـة ابن الصلاح، للإمـام بـدر الـدين الزركشي، ط: أضـواء

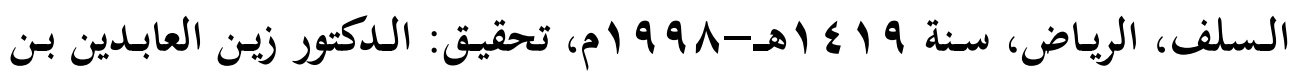

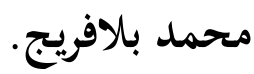
نيل الأماني، بفهرسة مسند العصر عبد الرحمن بن عبد الحي الكتاني، تأليف

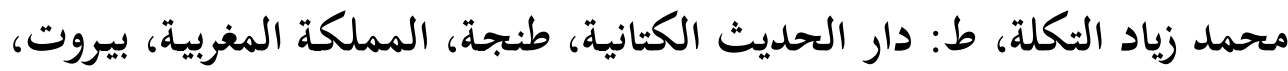

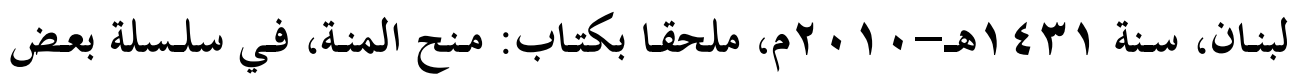
كتب السنة، لمسند العصر محمد عبد الحي الكتاني. 